\title{
Pathogenesis of psoriasis in the "omic" era. Part I. Epidemiology, clinical manifestation, immunological and neuroendocrine disturbances
}

\author{
Dominik Samotij ${ }^{1}$, Bogusław Nedoszytko², Joanna Bartosińska3 ${ }^{3}$ Aleksandra Batycka-Baran ${ }^{4}$, Rafał Czajkowski \\ Iwona T. Dobrucki ${ }^{6}$, Lawrence W. Dobrucki ${ }^{6,7,8,9}$, Magdalena Górecka-Sokołowskaa ${ }^{10}$, Anna Janaszak-Jasienicka ${ }^{8,9}$, \\ Dorota Krasowska ${ }^{3}$, Leszek Kalinowski ${ }^{8,9}$, Marta Macieja-Stawczyk ${ }^{2}$, Roman J. Nowicki², Agnieszka Owczarczyk-Saczonek ${ }^{11}$, \\ Agata Płoska ${ }^{8,9}$, Dorota Purzycka-Bohdan ${ }^{2}$, Adrianna Radulska $a^{8,9}$, Edyta Reszka ${ }^{12}$, Anna Siekierzycka ${ }^{8,9}$, Andrzej Słomiński ${ }^{13,14,15}$, \\ Radomir Słomiński ${ }^{16}$, Marta Sobalska-Kwapis ${ }^{17}$, Dominik Strapagie ${ }^{17}$, Aneta Szczerkowska-Dobosz ${ }^{2}$, Justyna Szczęch ${ }^{1}$, \\ Michał Żmijewski ${ }^{18}$, Adam Reich ${ }^{1}$
}

'Department of Dermatology, University of Rzeszow, Rzeszow, Poland

2Department of Dermatology, Venereology and Allergology, Medical University of Gdansk, Gdansk, Poland

${ }^{3}$ Department of Dermatology, Venereology and Pediatric Dermatology, Medical University of Lublin, Lublin, Poland

${ }^{4}$ Department of Dermatology, Venereology and Allergology, Wroclaw Medical University, Wroclaw, Poland

${ }^{5}$ Department of Dermatology and Venereology, Faculty of Medicine, Ludwik Rydygier Medical College in Bydgoszcz,

Nicolaus Copernicus University in Torun, Poland

${ }^{6}$ Beckman Institute for Advanced Science and Technology, Urbana, IL, USA

'Department of Bioengineering, University of Illinois at Urbana-Champaign, Urbana, IL, USA

${ }^{8}$ Department of Medical Laboratory Diagnostics, Medical University of Gdansk, Gdansk, Poland

${ }^{9}$ Biobanking and Biomolecular Resources Research Infrastructure, (BBMRI.PL), Gdansk, Poland

${ }^{10}$ Department of Dermatology, Sexually Transmitted Disorders and Immunodermatology, Jurasz University Hospital No. 1, Bydgoszcz,

Poland

${ }^{11}$ Department of Dermatology, Sexually Transmitted Diseases and Clinical Immunology, University of Warmia and Mazury, Olsztyn,

Poland

${ }^{12}$ Department of Molecular Genetics and Epigenetics, Nofer Institute of Occupational Medicine, Lodz, Poland

${ }^{13}$ Department of Dermatology, Birmingham, AL, USA

${ }^{14}$ Comprehensive Cancer Center, Cancer Chemoprevention Program, Birmingham, AL, USA

${ }^{15}$ VA Medical Center, Birmingham, AL, USA

${ }^{16}$ Department of Medicine, Division of Rheumatology, University of Alabama, Birmingham, AL, USA

${ }^{17}$ Biobank Lab, Department of Molecular Biophysics, Faculty of Biology and Environmental Protection, University of Lodz, Lodz, Poland

${ }^{18}$ Department of Histology, Medical University of Gdansk, Gdansk, Poland

Adv Dermatol Allergol 2020; XXXVII (2): 135-153

DOI: https://doi.org/10.5114/ada.2020.94832

\begin{abstract}
Psoriasis is a common, chronic, inflammatory, immune-mediated skin disease affecting about $2 \%$ of the world's population. According to current knowledge, psoriasis is a complex disease that involves various genes and environmental factors, such as stress, injuries, infections and certain medications. The chronic inflammation of psoriasis lesions develops upon epidermal infiltration, activation, and expansion of type 1 and type 17 Th cells. Despite the enormous progress in understanding the mechanisms that cause psoriasis, the target cells and antigens that drive pathogenic T cell responses in psoriatic lesions are still unproven and the autoimmune basis of psoriasis still remains hypothetical. However, since the identification of the Th17 cell subset, the IL-23/Th17 immune axis has been considered a key driver of psoriatic inflammation, which has led to the development of biologic agents that target crucial elements of this pathway. Here we present the current understanding of various aspects in psoriasis pathogenesis.
\end{abstract}

Key words: psoriasis, interleukins, autoimmunity, neurogenic inflammation, neoangiogenesis.

Address for correspondence: Prof. Adam Reich, Department of Dermatology, University of Rzeszow, 2 Szopena St, 35-055 Rzeszow, Poland, e-mail: adamandrzejreich@gmail.com

Received: 23.03.2020, accepted: 1.04.2020. 


\section{Introduction}

Psoriasis (PsO) is a common, chronic, inflammatory, immune-mediated skin disease affecting about $2 \%$ of the world's population. It is a lifelong stigmatizing disease with both physical and psychological burden that significantly reduces the patients' quality of life. According to current knowledge, psoriasis is a complex disease many genes and environmental factors, such as stress, injuries, infections and certain medications, may be responsible for its onset. Among the complex genetic nature of this disease, the most important role is played by $\mathrm{HLA}-C W^{*} 06$ allele - the main psoriasis susceptibility gene located at the PSORS-1 (Psoriasis Susceptibility) locus, which has been attributed up to $50 \%$ of the heritability of the disease, albeit more than 80 psoriasis susceptibility loci have been identified up to date. Corresponding genes to these loci are implicated in psoriasis immunopathogenesis pathways that involve complex, dysregulated interactions between innate and adaptive immune response, resulting in the hallmark of psoriasis - chronic, sustained inflammation with uncontrolled keratinocyte proliferation and up-normal differentiation.

Chronic inflammation of psoriasis lesions develops upon epidermal infiltration, activation, and expansion of type 1 and type 17 T cells. Moreover, marked oligoclonal expansion of the T-cell populations within the psoriatic plaque indicates that psoriatic T-cell activation may be driven by locally presented antigens (autoantigens), thus, psoriasis pathogenesis is suspected to be both, autoimmune and autoinflammatory. Despite enormous progress in psoriasis studies the target cells and antigens that drive pathogenic $C D 8^{+} T$ cell responses in psoriasis lesions are still unproven and the autoimmune basis of psoriasis still remains hypothetical.

Understanding the pathogenesis pathways of psoriasis through the introduction of new molecular research techniques has enabled the introduction of highly targeted and effective pathogenesis-based treatment with the potency of complete clearance of skin lesions. These accomplishments enable the future achievement of advanced goals to individualize treatment best suited for/to each patient targeting both psoriasis and associated diseases.

\section{Epidemiology and clinical manifestation}

Psoriasis is a chronic inflammatory, immune-mediated skin condition affecting more than 125 million individuals worldwide [1]. Given the high incidence of psoriasis and its significant impact on patients' quality of life and socio-economic consequences, the World Health Organization has recognized the disease as a global disease that is a challenge for the healthcare systems [1]. Its prevalence depends on ethnicity and the geographic region (sun exposure, climate). The worldwide prevalence of psoriasis ranges from $0.09 \%$ to $11.43 \%$ in adult population and $0.0-1.3 \%$ in children - with the average prevalence of $2 \%$ [2]. Psoriasis is a common disease among Caucasians in Europe and North America with the highest prevalence in the Scandinavian population [3-5]. The frequency of psoriasis is lower among people of Asian and African descent, and very few cases have been reported among Native Americans and Aboriginal Australians [2]. Analysis of demographic data from the Main Statistical Office for Polish provinces estimated the prevalence of psoriasis at $2.99 \%$ [6]. There is no gender predilection of the disease. Psoriasis may start at any age but bimodal age of onset is distinctive for this entity. Early onset of psoriasis (type I) starts before 40 years of age with a peak of onset between 20 and 29 years and late onset starts after 40 years of age (type II) with mean age of onset being 55-60 years [7].

Psoriasis is a clinically heterogeneous disease, with various forms, which are classified according to morphology, distribution and anatomical localization. The most common type of psoriasis, plaque psoriasis (psoriasis vulgaris), is characterized by infiltrated plaques covered by silvery scales, which may be either localized or generalized. The most severe form, erythroderma, affects the entire body surface and rarely, highly inflammatory forms characterized by eruptions of neutrophil-filled pustules. Other forms of psoriasis also include: generalized pustular psoriasis (GPP), the more localized palmo-plantar pustular psoriasis (PPP), and acrodermatitis continua of Hallopeau (ACH). Pustular psoriasis often coexists with plaque psoriasis or may start de novo.

Psoriasis is limited not only to the skin, but it is also a systemic, inflammatory disease with elevated levels of circulating proinflammatory cytokines. Its systemic nature is reflected in coexistence with many other conditions, such as cardiovascular disease, Crohn's disease, depression, metabolic syndrome and its components. Up to $30-35 \%$ of patients can develop psoriatic arthritis (PsA) which may have serious debilitating effects on joints. As a disease with genetic and immunological similarities that overlaps with other autoimmune and autoinflammatory diseases, psoriasis serves as a prototype disorder for research.

\section{Functional disturbances of innate lymphoid cells Innate lymphoid cells}

Innate lymphoid cells (ILCS) are part of the body's innate immunity. They perform antimicrobial functions, are involved in the formation of lymphoid tissue, tissue remodeling after damage (trauma), and in hemostasis of tissue stromal cells. They are a very diverse group of cells, which include natural killer (NK) cells, and ILC1 cells, whose main task is antitumor and antiviral protection [8, 9].

ILC3 cells are another subgroup of ILCS that were found in large numbers in psoriatic lesions and in the serum of patients suffering from psoriasis. They express $\mathrm{ROR} \gamma \delta$ transcription factor and require the ROR $\gamma \delta$ (RAR- 
related orphan receptor $\gamma$ ). These cells produce interleukin (IL)-17 and IL-22 upon stimulation with IL-1 $\beta$ and IL-23, which in turn constitute an important element in the pathogenesis and development of psoriasis. The development and activity of ILC3 depends on IL-7 $[8,10]$.

ILC2 cells are independent of ROR $\gamma$ t, while their development, similarly to ILC3 cells, is associated with IL-7. They take part in the production of IL-13, whose high concentration was observed in psoriatic lesions, although its role in the pathogenesis of psoriasis is still unclear $[9,11]$.

\section{Dendritic cells}

Dendritic cells (DCs) are diverse in origin and function. They take part in both the specific and non-specific immune responses. They are divided into myeloid (mDCs, DC1) and lymphoid (pDCs, DC2, plasmacytoid) cells. $\mathrm{mDCs}$ are formed in the bone marrow, which they leave as immature cells and migrate to various organs. They perform various functions depending on their degree of maturity:

- immature mDCs induce Th2 cells (type 2 T helper cells) and suppressor helper cells that synthesize IL-10 and transforming growth factor $\beta 1$ (TGF-b1),

- mature mDCs produce IL-12 and IL-23, stimulating Th1 and Th17 lymphocytes.

mDCs mature in different tissues, where they acquire the ability to be activated by various factors, e.g. tumor necrosis factor $\alpha$ (TNF- $\alpha$ ), lipopolysaccharide (LPS), IL-1 [12]. mDCs include Langerhans cells (LCS, CD1a), dermal dendritic cells (DDCs), otherwise known as interstitial DC cells (CD 11c), inflammatory DC IDEC (CD 206FcERI) and TIP-DC (TNF and-iNOS producing DC) $[12,13]$.

In psoriasis, IDEC secrete IL-12 and IL-23 and stimulate lymphocyte differentiation towards Th1 and type 1 cytotoxic T cells (TC1), while TIP-DC cells produce IL-20 and IL-23, which are responsible for the activation of keratinocytes and proliferation of Th17 lymphocytes producing pro-inflammatory IL-17 [12].

pDCs are a subpopulation of mDCs and lymphatic DCs that migrate to the skin only in the presence of pathological factors. The main role of DCs is antitumor and anti-infective protection, which they accomplish by presenting antigens to the cells of the immune system. In psoriasis, DCs induce a cascade of pathological reactions due to their incorrect activation.

Activation of DCs (in this case pDCs) in patients with psoriasis occurs through misdiagnosed (treated as foreign) genetic material from own damaged keratinocytes. As a result of this reaction, IFN- $\alpha$ (interferon $\alpha$ ) is overproduced, which triggers the immune cascade leading to the development of psoriatic skin inflammation. Significant participation of DCs in the pathogenesis of psoriasis is also manifested by a higher concentration of these cells in the skin of the psoriasis sufferers compared to healthy individuals $[12,13]$. pDCs also play an important role in the presentation of viral genetic material, which in over $95 \%$ stimulates the synthesis of type 1 IFNs ( $\alpha$ and $\beta$ ) $[12,13]$. IFN stimulates IL-2 receptor expression on lymphocytes, which activates Th1 and Tc1 lymphocytes.

The function of DCs described above is normal in viral infections and explains the exacerbation of the inflammatory process in psoriasis patients in the course of such infections. In psoriatic lesions, activity of all types of DC increases, but mainly IDEC, TIP-DC and PDC.

\section{Mast cells}

Mast cells are derived from the bone marrow progenitor cell, from where they migrate to tissues, where, under the influence of cytokines, they differentiate and mature. Stem cell factor (SCF) and its receptor Kit are involved in the differentiation and proliferation of mast cells. After SCF binds to the Kit receptor, mast cell proliferation increases [14, 15].

Mast cells located in the skin contain tryptase, chymase, and carboxypeptidase A in their granules and constitute so-called MCTC phenotype of mast cells. We also distinguish the MCT and MCC phenotypes that occur in mucous membranes and inflammatory infiltrates [14].

Active mast cells with the MCTC phenotype are observed in large numbers in psoriatic lesions. It has also been shown that the concentration of SCF is significantly increased in the skin of patients suffering from psoriasis compared to the skin of healthy individuals [14]. Activation of mast cells occurs under the influence of bacteria, parasites, drugs, food allergens, physical factors such as mechanical trauma of the skin, high temperature, ultraviolet radiation, and emotional stress. Active mast cells release the granule content through degranulation and this mechanism is typical for allergic reactions and anaphylaxis, however, the release of proinflammatory cytokines and other substances is also possible without degranulation as it occurs in chronic inflammatory diseases, including psoriasis [16].

In psoriasis, stress is one of the factors responsible for mast cell activation, as evidenced by the presence of elevated serum corticotropin-releasing hormone ( $\mathrm{CRH})$. Other substances that are secreted by mast cells include IL-1 and interleukins from the IL-1 family, including IL-18, IL-33, TNF- $\alpha$, IFN- $\gamma$, TGF- $\beta$, SCF, granulocyte-macrophage colony-stimulating factor (GM-CSF), CCL2, CCL3, CCL4, CCL5, and CCL20 $[14,15]$. Cutaneous mast cells are located in the vicinity of blood vessels and sensory nerve endings $[14,15]$. It implies the possibility of mast cells' activation by neuropeptides, such as substance P (SP), which maintains skin inflammation.

\section{Monocytes and macrophages}

Monocytes belong to leukocytes and are immune effector cells. They come from the bone marrow and circulate in the peripheral blood and are present in the spleen. They have the ability to migrate from blood to tissues, 
mainly during inflammation. Then they differentiate into inflammatory macrophages and dendritic cells. They produce inflammatory cytokines and, by phagocytosis, remove residues of other cells and toxic molecules [17].

In psoriasis, keratinocytes are the source of MCP-1/ CCL2 (monocyte chemotactic protein 1). CCL2 is a chemokine that increases the migration of monocytes from the bloodstream to the skin by chemotaxis. Monocytes through CCR2 receptors on their surface bind to CCL2. This causes the differentiation of monocytes in the skin into macrophages, which behave like antigen presenting cells producing TNF- $\alpha$, which further enhances CCL2 production. In contrast to neutrophils or T lymphocytes located mainly in the epidermis, macrophages are mostly located in the dermis [18].

The involvement of macrophages in the pathogenesis of psoriasis is not fully understood. Based on available data in the literature, it is known that psoriatic lesions have an increased number of macrophages compared to their number in the healthy skin or in the skin of patients after successful anti-psoriatic therapy. After their activation cutaneous macrophages produce TNF- $\alpha$ and vascular endothelial growth factor (VEGF) intensifying the process of angiogenesis [19].

\section{Neutrophils}

Neutrophils are often the first line of defense in the course of acute bacterial infections. They have the ability to form neutrophil extracellular traps (NETs) built mainly of genetic material from neutrophils, in which they bind to antimicrobial peptides (AMPs), protecting the body against infection. NETs also play an important role in initiating autoimmune diseases, a phenomenon which has also been observed in the course of psoriasis [15, 19]. In psoriasis, neutrophils are mainly seen in the epidermis. They intensify proliferation and accelerate keratinocyte differentiation and activate $T$ lymphocytes. They also produce chemokines such as CXCL1, CXCL2, CXCL8 (IL-8) and interleukins (e.g. IL-18) [9, 13]. The described properties of neutrophils explain the stimulation of their migration into the sites of bacterial infection in patients with psoriasis and the intensification of angiogenesis. Active neutrophils produce pro-inflammatory cytokines, including IL-17 and proteases. One of them is elastase, which is secreted by neutrophils in response to TNF- $\alpha$ and IL-8. These phenomena stimulate the proliferation of keratinocytes and intensify and maintain skin inflammation [19].

\section{Keratinocytes}

Keratinocytes play an important role in initiating the development of psoriatic lesions and the chronicity of inflammation [19]. These cells perform not only protective and barrier functions, but they are also involved in immunological processes. They protect our body against harmful physical, chemical and biological factors in the mechanism of both innate and acquired immune responses.

An important function of the skin (including keratinocytes) is the production of AMPs. These include $\beta$-defensins (HBDs), psoriasin, dermicin, cathelicidins (LL-37), lysozyme, RNase 7, elafins, adrenomedullins, and leukocyte protease inhibitors. Secretion of AMPs is caused, among others, by trauma and infectious (viral, bacterial, fungal, parasitic) agents. Disturbances in the production of AMPs affect the pathogenesis of many dermatoses, including psoriasis, in which an increased expression of mainly $\beta$-defensins, LL-37, RNase 7, psoriasin and lysozyme is observed. Increased expression of AMPs in the course of psoriasis also results from the increased production of proinflammatory cytokines such as TNF- $\alpha$, IL-1, IL-6, IFN- $\gamma$ produced e.g. by NKT (natural killer T-cells) or macrophages. The effect of overexpression of AMPs is a reduced susceptibility to skin infections (e.g. high concentration of LL-37 protects patients suffering from psoriasis against staphylococcal infection of the skin) [20].

Damaged keratinocytes produce large amounts of AMPs that affect the production of proinflammatory cytokines such as IL-6 and IL-10; chemokines such as IL-8 (CXCL8), CXCL10, CCL20, which stimulate the migration of macrophages, neutrophils, myeloid DCs and Th17 lymphocytes into the skin, and IL-1 $\beta$ and IL-18, whose presence induces the development of inflammation of the skin due to injury. IL-1 $\beta$ increases TNF- $\alpha$ production by keratinocytes. During an infection, TNF- $\alpha$ and IFN- $\alpha$ are synthesized. TNF- $\alpha$ induces the activation of CCL2O chemokine and mediates neutrophil recruitment by stimulation of CXCL8 chemokines produced by keratinocytes. IFN- $\alpha$ can stimulate the synthesis of CXCL10 and CXCL11 in keratinocytes leading to the recruitment of Th1 lymphocytes.

IL-18 and IL-1 $\beta$ are also responsible for the differentiation of Th1 and Th17 lymphocytes, which in active forms secrete IL-22 and IL-17. Both cytokines in turn intensify proliferation and activate keratinocytes, thus maintaining chronic inflammation $[19,21]$. The literature describes the deletion of the LCE3B and LCE3C genes, the lack of which impairs the proper functioning of the epidermal barrier by changing the composition of proteins building the stratum corneum. In this situation, even the slightest injury to the epidermis causes the development of chronic inflammation and induces the auto-inflammatory mechanisms described above [19].

\section{Natural killer cells and other cells}

NK cells are involved in the antiviral and anti-tumor response. $\mathrm{CD}^{5} 6^{+}, \mathrm{CD}_{16}{ }^{+} \mathrm{NK}$ cells in psoriasis patients are responsible for the production of proinflammatory cytokines such as IFN- $\gamma$, TNF- $\alpha$, IL-17 and IL-22. They also affect the activity of DCs, macrophages and T lymphocytes $[10,22]$. 
NKT cells are subpopulations of $T \alpha / \beta$ lymphocytes and express NK cell receptors. They are, therefore, cells with common features of both T cells and NK cells. On their surface they have a Toll-like receptor (TCR) and surface antigens characteristic of NK cells. In contrast to $T$ lymphocytes, which only recognize peptide antigens, they are cells that recognize the lipid and glycolipid antigens presented by the CD1d molecule. They have the ability to react quickly to the presented antigen and rapidly secrete proinflammatory cytokines such as IFN- $\gamma$, IL-2, IL-4, IL-17, IL-22, and TNF- $\alpha$. They have the ability to stimulate other cells of the immune system, such as NK cells, T cells, DCs and B cells. NKT cells combine specific and non-specific immunity. They play an important role in the immune response in the course of infections, cancers and psoriasis etc. [10, 23].

The number of both cells described above is higher in psoriatic lesions, which undoubtedly indicates their effect on the pathogenesis and maintenance of inflammation, although their exact function and pathogenetic role in psoriasis has not been fully understood. Moreover, NKT cells have receptors such as CXCR3, CCR5 and CCR6, which facilitate their migration to psoriatic lesions [10].

Proinflammatory cytokines, such as IL-23, IL-17, and Th $\gamma / \delta$ lymphocytes play an important role in the pathogenesis of psoriasis. IL-23 is produced by DCs and macrophages found in the skin. This cytokine binds to its receptor (IL-23R) located on the cutaneous Th $\gamma / \delta$ lymphocytes, which synthesize significant amounts of IL-17, which is next responsible for psoriasis progression [21, 24].

\section{Polarization towards Th1/Th17/Th22 cells}

Psoriasis is a Th1-mediated chronic inflammatory skin disease. Since the identification of Th17 cell subset, the IL-23/Th17 immune axis has been considered a key driver of psoriatic inflammation, which has led to the development of biologic agents that target crucial elements of this pathway $[25,26]$. Subsequently, after the role of IL-22 has been studied on a mouse model, psoriasis is currently regarded as a Th1/Th17/Th22-mediated condition as increased circulating Th1, Th17, and Th22 cell levels have been identified $[27,28]$. Keratinocytes participate in innate immune responses by increased synthesis of innate effector cells, as well as in adaptive immune responses by directing migration of new $T$ cell subsets into the skin via cytokine production $[29,30]$.

In the early, initiation phase of psoriasis, DCs are activated and start producing inflammatory mediators [30]. pDCs express Toll-like receptor (TLR)7 and TLR9 which are normally tolerant to self-DNA/RNA as they detect pathogen-encoded nucleic acids [31-35]. In the individuals that are genetically predisposed, exposure to certain triggering factors, such as epidermal injury can activate keratinocytes to produce excessive amounts of AMPs, such as $\beta$-defensins and cathelicidin LL-37 [36, 37]. Stressed or dying epidermal cells also release self-nucleic acids, self-DNA and self-RNA [38]. LL-37 binds to self-DNA and forms condensed complexes protected from degradation which are translocated into the endocytic compartments of pDCs. LL-37/DNA complexes are able to activate TLR7 and TLR9, thereby induce IFN- $\alpha$ production by pDCs via cytosolic sensors and trigger further activation of pDCs and ultimately activate dermal DCs [34, 39-41]. LL-37 is an essential molecule in psoriasis pathophysiology as it is necessary to break the innate tolerance, it mediates recognition of self-DNA and self-RNA by pDCs and activates them to initiate the disease development [42]. In addition, self-RNA/LL-37 complexes stimulate mDCs to mature after the production of TNF- $\alpha$ and IL- 6 further driving $T$ cell activation and cytokine production $[36,38]$. Extracellular DNA has recently been found in the epidermis in association with NETs further supporting the above described model of psoriasis initiation [30]. Activated DCs are transformed into mature antigen presenting cells and are able to produce TNF- $\alpha$, IL-23 and IL-12 which interact with naïve T cells. IL-23, in the presence of IL- 6 and TGF- $\beta$, with the additional potentiating effect of IL- $1 \beta$ and TNF- $\alpha$, determines the differentiation of $\mathrm{CD}^{+}$naïve cells into highly pathogenic Th17 cells which produce IL-17, IL-22 and TNF- $\alpha[43,44]$. IL-23, in association with IL- 6 and TNF- $\alpha$, also promotes the production of Th22 cells which secrete IL-22 and TNF- $\alpha$ [45]. All these mediators further maintain keratinocytes activation producing self-antigen LL-37 for psoriatic autoreactive $T$ cells, proinflammatory cytokines, such as TNF- $\alpha, I L-1 \beta$, IL-6, chemokines and S100 proteins, propagating the chronic inflammation [42, 46, 47]. Taken together, these proteins increase keratinocyte proliferation, production of AMPs and chemokines which promote angiogenesis and neovascularization, neutrophil recruitment, thereby sustain skin inflammation [48].

\section{Interleukin 17}

The IL-17 cytokine family consists of six isoforms named IL-17 A-F. IL-17A and IL-17F are the most closely related and share overlapping biological functions [49]. These cytokines are involved in the protective immune responses (via IL-26) in mucoepithelial infections, particularly those caused by staphylococci and extracellular fungi inducing tissue inflammation [50-52]. High expression of IL-17A, E, and $F$ is present in psoriatic plaques and interleukin 17 receptor A (IL-17RA) is highly expressed on the cell surface of keratinocytes and in psoriatic lesions $[27,53,54]$. Th17 (CD4+) cells are a major source of IL-17A, albeit emerging evidence indicates that it can also be produced by CD8 ${ }^{+} T$ cells and $\gamma \delta$ T cells [25], NKT cells $[55,56]$, mast cells and neutrophils [57]. IL-17 is a key effector cytokine downstream of IL-23 that drives psoriatic inflammation [58]. The IL-17 receptor is expressed on a broad range of cells, including T cells, epithelial cells and fibroblasts [59-61]. IL-17 induces IL-17 receptor-de- 
pendent proliferation of keratinocytes and production of proinflammatory cytokines, most importantly IL-1 $\beta$, IL-6 and TNF, and antimicrobial peptides, such as $\beta$-defensin and matrix metalloprotease 9 [62-64].

\section{Interleukin 23}

IL-23 was identified in 2000 as a part of the IL-12 family, itself a part of the IL- 6 superfamily, of heterodimeric cytokines and is composed of the IL-12/IL-23 p40 subunit and a unique p19 subunit [65]. IL-23 is a key cytokine involved in antibacterial and antifungal immune responses and is produced by several cells, predominantly by dendritic cells and activated monocytes [66, 67]. Importantly, dysregulation of IL-23 production promotes autoinflammation [68]. IL-23 signals through a receptor complex composed of the IL-23R subunit and the IL-12R $\beta 1$ subunit, common with IL-12 $[69,70]$. The IL-23 receptor complex is expressed on the surface of lymphoid cells (such as $\alpha \beta$ and $\gamma \delta$ T cells), innate lymphoid cells, and cells of myeloid origin, including dendritic cells, macrophages, and monocytes [71]. IL-23 binding to its receptor complex predominantly activates signal transducer and activator of transcription 3 (STAT3), which is particularly important in psoriasis. This further leads to IL-23-dependent gene expression [70, 72]. IL-23 is an upstream regulatory cytokine that takes action early in the inflammatory cascade in psoriasis; it acts on the already committed Th17 population to maintain the phenotype and is crucial in the production of downstream effector cytokines, such as IL-17A, IL-17F, IL-22, IL-21 and TNF- $\alpha$ which eventually contribute to the formation of psoriatic plaques $[25,73,74]$. Importantly, IL-23 is not required for early Th17 cell development since the IL-23R is not expressed on naïve T cells. The initial differentiation of naïve T cells into Th17 cells requires the presence of TGF- $\beta, \mathrm{IL}-6$, and IL-1 $\beta$ [75-78].

The recent advances in the understanding of psoriasis pathogenesis have solidified the critical role of IL-23. The basic role of IL-23 in the pathogenesis of psoriasis has been clarified, and it is closely associated with the Th17 lineage.

\section{Tumor necrosis factor $\alpha$}

TNF- $\alpha$ plays a pivotal role in the pathogenesis of psoriasis; it is the first cytokine to be successfully targeted by biologic agents [79]. TNF- $\alpha$ production is significantly elevated in psoriatic lesional skin as compared to nonlesional and healthy skin $[80,81]$. Numerous studies showed that circulating levels of TNF- $\alpha$ are elevated in psoriasis patients and correlate with disease severity [82-84]. Other than keratinocytes, different cell types, such as macrophages/monocytes, mast cells, BDCA-1 inflammatory DCs, and activated T cells, are sources of TNF- $\alpha$ in the stimulated skin $[85,86]$. Stimulation with TNF- $\alpha$ induces not only immune and inflammatory responses orchestrated by keratinocytes but also tissue remodeling, cell motility, cell cycling, and apoptosis.
TNF- $\alpha$ is a powerful inducer of inflammatory gene products in keratinocytes [87]. It shows proinflammatory activity which is potentiated by synergistic interactions with other key cytokines including IL-17, IFN- $\gamma$ and IL-2 $[62,83]$. It is considered an upstream mediator in the IL-23/IL-17 pathway acting as an inducer of IL-23 synthesis by DCs; the clinical improvement seen with TNF- $\alpha$ blockade is linked to suppression of the IL-23/Th17 axis [10].

TNF- $\alpha$ activates the nuclear factor $\kappa \mathrm{B}(\mathrm{NF}-\kappa \mathrm{B})$ signaling pathway, which affects cell survival, proliferation and antiapoptotic effects of lymphocytes and keratinocytes [88]. In addition, TNF- $\alpha$ stimulates keratinocytes to produce IL-8, which leads to microabscess formation by enhancing neutrophil recruitment in psoriasis [89]. TNF- $\alpha$ induces Th17 to produce proinflammatory cytokines through the NF- $\kappa$ B pathway in psoriatic lesions, and blockade of the NF- $\mathrm{B}$ p pathway results in a loss of IL-17A production from $\mathrm{CD}^{+} \mathrm{T}$ cells [90].

\section{Interleukin 22}

IL-22 is an IL-10 family cytokine which plays an important role in the mucosal and barrier organ immunity. Of the IL-10-related cytokines, IL-22 is the one that has been the most studied in relation to skin inflammation [59, 91]. IL-22 is produced in combination with IL-17, similarly to Th17, ILC3, and mast cells, or exclusively by specific $\mathrm{CD}^{+} \mathrm{T}$ and $\mathrm{CD} 8^{+} \mathrm{T}$ cell subsets, namely Th22 and TC22 cells, respectively [92-96]. IL-22 receptor is composed of the IL-22R chain and the IL-10R2 chain. The IL-10R2 chain is expressed broadly, whereas IL-22R is predominantly expressed on epithelial cells $[59,97]$. Binding of IL-22 to its receptor complex leads to the activation of STAT3 and the ERK1/2 pathway [98-100]. Notably, IL-22 production is regulated differently than other Th17-associated cytokines; its expression is less dependent on the transcription factor ROR $\gamma$ t and more dependent on the aryl hydrocarbon receptor (AhR), which is a ligand transcription factor in Th17 cells being mandatory for the production of IL-22 [101]. Increased expression of IL-22 has been detected in both lesional skin and in the blood, and IL-22 levels correlate with disease severity and significantly decrease during treatment; its effects are mostly directed towards regulating keratinocyte functions [28, 102]. Therefore, IL-22 is involved in enhancing keratinocyte migration, increasing epidermal thickness, inducing chemokine production, AMPs, neutrophil chemoattractants and production of MMPs [10]. IL-22 has a well-documented role in the pathogenesis of psoriasis. Even though fenakinumab, IL-22-neutralizing antibody, was discontinued, IL-22 is still a potential target for antipsoriatic treatments [100, 103] (Table 1).

\section{Regulatory $\mathrm{T}$ cells in psoriasis}

Regulatory $T\left(T_{\text {Reg }}\right)$ cells, defined by the expression of CD4, CD25 and the transcription factor forkhead box P3 
Table 1. Cytokines related to the Th1/Th17 axis in psoriasis

\begin{tabular}{|c|c|c|c|c|c|}
\hline Cytokine & $\begin{array}{l}\text { Cellular } \\
\text { source }\end{array}$ & Receptor & Target & Immunological effect & $\begin{array}{l}\text { Role in pathogenesis } \\
\text { of plaque psoriasis }\end{array}$ \\
\hline IFN- $\gamma$ & $\begin{array}{l}\text { NK cells } \\
\text { NKT cells } \\
\text { Th1 CD4 and } \\
\text { CD8 cytotoxic } \\
\text { T lymphocyte } \\
\text { effector } \\
\text { T cells }\end{array}$ & IFN $\gamma$ R & $\mathrm{mDCs}$ & $\begin{array}{l}\text { Upregulates the expression of IL-22 receptor } \\
\text { in keratinocytes } \\
\text { Regulates keratinocyte differentiation }\end{array}$ & $\begin{array}{l}\text { Skin inflammation } \\
\text { Angiogenesis } \\
\text { Th17 amplification } \\
\text { Keratinocyte hyperproliferation } \\
\text { and epidermal hyperplasia } \\
\text { DCs maturation } \\
\text { Along with TNF- } \alpha \text {, exhibits } \\
\text { proatherosclerotic properties }\end{array}$ \\
\hline IL-23 & $\begin{array}{l}\text { Macrophages } \\
\text { Tip-DCs } \\
\text { Dermal DCs }\end{array}$ & $\begin{array}{l}\text { IL12R } \beta / \\
\text { IL23R }\end{array}$ & Th17 & $\begin{array}{l}\text { Induces dermal } \gamma \delta \text { T cells activation and } \\
\text { expansion to secrete IL-17, IL-22 and TNF- } \alpha \\
\text { Drives and maintains the differentiation of } \\
\text { Th17 cells } \\
\text { Stimulates antigen presentation by DCs } \\
\text { Stimulates IFN- } \gamma \text { secretion }\end{array}$ & $\begin{array}{l}\text { Th17 differentiation } \\
\text { mDCs activation } \\
\text { Chronic inflammation }\end{array}$ \\
\hline $\begin{array}{l}\text { IL-17 } \\
\text { (IL-17A } \\
\text { and } \\
\text { IL-17F) }\end{array}$ & $\begin{array}{l}\text { Th17 cells } \\
\text { Tc17 cells } \\
\text { NK cells } \\
\text { NKT cells } \\
\gamma \delta T \text { cells } \\
\alpha \beta T \text { cells } \\
\text { ILC3s } \\
\text { Neutrophils } \\
\text { Mast cells }\end{array}$ & $\begin{array}{l}\text { IL17RA/ } \\
\text { IL17RC }\end{array}$ & $\begin{array}{l}\text { Keratinocytes } \\
\text { Fibroblasts } \\
\text { Osteoblasts } \\
\text { Endothelial cells }\end{array}$ & $\begin{array}{l}\text { Increases the expression of cathelicidin LL-37 } \\
\text { Induces the expression of important } \\
\text { proinflammatory cytokines, including IL-1 } 1 \beta \text {, } \\
\text { IL-6, GM-CSF, G-CSF and TNF from fibroblasts } \\
\text { and macrophages } \\
\text { Enhances the expression of chemokines }\end{array}$ & $\begin{array}{l}\text { Inflammation } \\
\text { Neutrophil recruitment } \\
\text { Angiogenesis } \\
\text { Contributes to development of } \\
\text { cardiovascular comorbidities }\end{array}$ \\
\hline IL-22 & $\begin{array}{l}\text { Th17 cells } \\
\text { NKT cells } \\
\gamma \delta \text { T cells } \\
\text { ILCs } \\
\text { Macrophages } \\
\text { Neutrophils }\end{array}$ & $\begin{array}{l}\text { IL22R1/ } \\
\text { IL10R } \beta\end{array}$ & $\begin{array}{l}\text { Keratinocytes } \\
\text { Dermal } \\
\text { fibroblasts }\end{array}$ & $\begin{array}{l}\text { Induces the expression of proinflammatory } \\
\text { cytokines (IL-1, IL-6, IL-8, IL-11) } \\
\text { Promotes the production of neutrophil- } \\
\text { attracting chemokines }\end{array}$ & $\begin{array}{l}\text { Host defense (induces the } \\
\text { production of antimicrobial } \\
\text { peptides and chemokines) } \\
\text { Stimulates proliferation of } \\
\text { keratinocytes and dermal } \\
\text { fibroblasts } \\
\text { Inhibits terminal differentiation } \\
\text { of keratinocytes } \\
\text { Inflammation }\end{array}$ \\
\hline IL-1 $\beta$ & $\begin{array}{l}\text { Macrophages } \\
\text { T cells } \\
\text { Keratinocytes } \\
\text { DCs }\end{array}$ & ILR1 & $\begin{array}{l}\text { Keratinocytes } \\
\text { Endothelial cells }\end{array}$ & $\begin{array}{l}\text { Promotes Th17 cells differentiation from naïve } \\
\text { T cells } \\
\text { Induces dermal } \gamma \delta \text { T cell proliferation and IL-17 } \\
\text { production } \\
\text { Stimulates keratinocytes to secrete } \\
\text { chemokines which chemoattract IL-17-capable } \\
\text { producing T cells }\end{array}$ & $\begin{array}{l}\text { Inflammation } \\
\text { Angiogenesis } \\
\text { Th17 amplification }\end{array}$ \\
\hline TNF- $\alpha$ & $\begin{array}{l}\text { Macrophages } \\
\text { DCs } \\
\text { Keratinocytes } \\
\text { Fibroblasts } \\
\text { Th17 cells } \\
\text { Adipocytes }\end{array}$ & $\begin{array}{l}\text { TNF- } \alpha \text { R1 } \\
(p 55) / T N F- \\
\alpha R 2(p 75)\end{array}$ & $\begin{array}{l}\text { mDCs } \\
\text { Macrophages } \\
\text { Keratinocytes } \\
\text { Adipocytes }\end{array}$ & $\begin{array}{l}\text { Promotes inflammation through synergism } \\
\text { with IL-17A and development and maturation } \\
\text { of mDCs } \\
\text { Facilitates entry of inflammatory cells into } \\
\text { lesional skin through induction of adhesion } \\
\text { molecules production } \\
\text { Stimulates keratinocytes to release other } \\
\text { proinflammatory mediators } \\
\text { Activates dermal macrophages and DCs } \\
\text { Increases production of IL-1, IL-6, IL-8 }\end{array}$ & $\begin{array}{l}\text { Proinflammatory } \\
\text { DCs activation } \\
\text { Recruitment of immune cells } \\
\text { Keratinocyte proliferation } \\
\text { Th17 amplification } \\
\text { Metabolic dysregulation }\end{array}$ \\
\hline IL-6 & $\begin{array}{l}\text { Macrophages } \\
\text { Monocytes } \\
\text { T cells } \\
\text { Th17 cells } \\
\text { Keratinocytes } \\
\text { Fibroblasts } \\
\text { Endothelial } \\
\text { cells } \\
\text { DCs }\end{array}$ & $\begin{array}{l}\text { IL-6R/ } \\
\text { gp130 }\end{array}$ & $\begin{array}{l}\text { DCs } \\
\text { Macrophages } \\
\text { T cells }\end{array}$ & $\begin{array}{l}\text { Th17 cells differentiation from naïve CD4+ T cells } \\
\text { Increases Th17/T } T_{\text {reg }} \text { ratio } \\
\text { linduces excessive production of VEGF } \\
\text { Promotes differentiation of myeloid progenitors } \\
\text { to neutrophils } \\
\text { Reinforcement of Th1/Th17 axis } \\
\text { Facilitates IL-22-mediated epidermal hyperplasia } \\
\text { Key mediator of IL-23/Th17-driven cutaneous } \\
\text { inflammation }\end{array}$ & $\begin{array}{l}\text { Keratinocyte proliferation } \\
\text { Angiogenesis } \\
\text { Treg inhibition }\end{array}$ \\
\hline
\end{tabular}


Table 1. Cont.

\begin{tabular}{|c|c|c|c|c|c|}
\hline Cytokine & $\begin{array}{l}\text { Cellular } \\
\text { source }\end{array}$ & Receptor & Target & Immunological effect & $\begin{array}{l}\text { Role in pathogenesis } \\
\text { of plaque psoriasis }\end{array}$ \\
\hline IL-12 & $\begin{array}{l}\text { Monocytes } \\
\text { Macrophages } \\
\text { DCs } \\
\text { B cells } \\
\text { Th1 cells }\end{array}$ & $\begin{array}{l}\text { IL-12R } \beta \text { 1/2 } \\
\text { (IL-12R is a } \\
\text { heterodimer } \\
\text { composed } \\
\text { of IL-12R } \beta 1 \\
\text { and } \\
\text { IL-12Rß2) }\end{array}$ & $\begin{array}{l}\text { Th1 cells } \\
\text { Activates NK } \\
\text { cells to IFN- } \gamma \\
\text { production } \\
\text { Chemotactic } \\
\text { factor for NK } \\
\text { cell infiltration }\end{array}$ & $\begin{array}{l}\text { Induction of IFN- } \gamma \text { production from NK cells } \\
\text { and T cells } \\
\text { Enhancement of NK and T cell cytotoxicity } \\
\text { Differentiation of naïve T cells into Th1 } \\
\text { effectors } \\
\text { Key role in development of cell-mediated } \\
\text { immunity }\end{array}$ & $\begin{array}{l}\text { Th1 differentiation } \\
\text { Inflammation } \\
\text { NK cells activation }\end{array}$ \\
\hline
\end{tabular}

CRP - C-reactive protein, DCS - dendritic cells, IFN- $\gamma$ - interferon- $\gamma$, IL - interleukin, ILCS - innate lymphoid cells, ILC3s - group 3 innate lymphoid cells, mDCS myeloid dendritic cells, NK - natural killer cells, NKT - natural killer T cells, pDCs - plasmacytoid dendritic cells, Th - T helper, Tip-DCs - dendritic cells that release tumor necrosis factor and nitric oxide, TNF- $\alpha$-tumor necrosis factor $\alpha, T_{\text {reg }}$-regulatory T cells, VEGF-vascular endothelial growth factor.

(FoxP3), represent a distinct lineage of T lymphocytes. They have been identified in the human peripheral blood and in the human normal skin, where they represent about $5-10 \%$ of resident T-cells. $T_{\text {Reg }}$ cells have a central role in the induction and maintenance of immune tolerance and protecting an individual from autoimmunity. The lack of these cells results in severe autoimmunity. They suppress immune response through contact-dependent mechanisms and production of soluble factors, including TGF- $\beta$, IL-10 and IL-35 [104, 105]. $T_{\text {Reg }}$ may exert their suppressive functions by a direct cytotoxic effect, modulation of dendritic cell functions and metabolic disruption [105]. $T_{\text {Reg }}$ cells are divided into thymus derived natural $T_{\text {Reg }}$ cells and periphery-induced adaptive $T_{\text {Reg }}$ cells. Some other populations of $T$ cells with regulatory and suppressive potential have been identified such as IL-10- and TGF- $\beta$-producing type 1 regulatory $T\left(T_{R} 1\right)$ cells and TGF- $\beta$-producing T helper 3 (Th3) cells, however these cells do not have unique cell surface markers and their precise functions remain to be elucidated [104, 105].

There is evidence that supports the involvement of impaired $T$ cell regulation in the pathogenesis of psoriasis [104, 105]. Several studies showed an increased number of $\mathrm{T}_{\text {Reg }}\left(\mathrm{FoxP3}^{+}\right)$cells both in lesional psoriatic skin and in peripheral blood of patients with psoriasis [106-109]. The increased number of $T_{\text {Reg }}$ cells in peripheral blood was positively associated with the disease activity index [109]. However, some studies provided contrary results showing a decreased number of $T_{\text {Reg }}$ cells in peripheral blood as well as in lesional skin in the acute phase of the disease [110-112]. Nevertheless, numerous studies demonstrated relative imbalance favoring effector T cells in psoriasis $[104,108,113]$. $T_{\text {Reg }}$ cells, both in the peripheral blood and lesional skin of patients with psoriasis, have impaired ability to suppress effector T cells. Additionally, effector T cells from patients with psoriasis have enhanced proliferative capacity [113]. Zhang et al. reported that $C D 4^{+}, C D 25^{+} T_{\text {Reg }}$ cells derived from hematopoietic CD34+ cells of patients with psoriasis were functionally deficient in vitro to restrain effector T cells. Therefore, the authors suggested involvement of genetic background in the failure of T cells regulation in psoriasis [114]. Impaired suppressive function of $T_{\text {Reg }}$ cells in psoriasis may result from proinflammatory cytokine milieu, especially high levels of IL-6 in psoriatic lesions $[104,105,115,116]$. An increased cell surface expression of the IL-6 receptor was found both on $T_{\text {Reg }}$ cells and effector T cells in psoriatic lesions. Goodman et al. showed that IL-6 specific antibody can reverse the failure in $T_{\text {Reg }}$ cell-mediated suppression of effector T cells in patients with psoriasis [115]. Further, IL-6 enhanced the resistance of effector $T$ cells to $T_{\text {Reg }}$ cells suppression. Therefore, two possible mechanisms of impaired T-cell regulation in psoriasis have been proposed: decreased suppressive function of $T_{\text {Reg }}$ cells and resistance of effector $T$ cells to their suppression [104, 105, 115]. Bovenschen et al. showed that in patients with psoriasis, $T_{\text {Reg }}$ cells turn into IL-17 expressing cells which perpetuate an autoinflammatory cascade [116]. They demonstrated the presence of $\mathrm{IL}-17^{+}$, Foxp $3^{+}, \mathrm{CD}^{+}$cells in psoriatic lesions which potentially become Th17 over time. This differentiation was driven by psoriatic cytokine milieu. IL-23 has been identified as a cytokine primarily responsible for this conversion. Authors identified epigenetic modification, histone/protein deacetylation as a key factor underlying $T_{\text {Reg }}$ cell plasticity and conversion into potentially pathogenic effector T-cells $[106,117]$. Recently, it has been demonstrated that IL-23 induces generation of $\mathrm{CD}^{+}$, Foxp3 $3^{+}$, ROR $\gamma \mathrm{t}^{+}, \mathrm{IL}^{-17 \mathrm{~A}^{+}}$ cells from $T_{\text {Reg }}$ cells in vitro [118].

FOXP3 is the master transcription factor for the development and function of $\mathrm{T}_{\text {Reg }}$ cells. Zhao et al. showed that overexpression of microRNA-210 (miR-210) in CD4+ T cells from patients with psoriasis inhibited FOXP3 expression and impaired immunosuppressive functions of $T_{\text {Reg }}$ cells [119]. In contrast, inhibition of miR-210 increased FOXP3 expression and reversed the immune dysfunction of CD4+ $\mathrm{T}$ cells. Therefore, authors proposed the mechanism of immune dysfunction in psoriasis via miR-210 overexpression targeting FOXP3 expression in CD4 ${ }^{+} T$ cells [119]. Some authors suggested that single nucleotide polymorphism(s) (SNPS) of FOXP3, such as intron-1 rs3761548, may be responsible for the defective transcription of FOXP3 in psoriasis. Keijsers et al. found that the ratio of $\mathrm{T}_{\mathrm{Reg}}\left(\mathrm{FOXP3}^{+}\right)$vs. CD4 ${ }^{+} \mathrm{T}$ cells was higher 
in the distant uninvolved psoriatic skin as compared to perilesional and lesional psoriatic skin. They then suggest that impaired T cells regulation as an important trigger for the development of psoriatic skin lesions [120]. $\mathrm{T}_{\text {Reg }}$ cell dysfunction in autoimmune disease may be due to inadequate expression of cell surface molecules, involved in the suppressive mechanism, such as cytotoxic T lymphocyte antigen 4 (CTLA4), CD95 (FAS) [104]. Kim et al. found downregulation of negative immune regulatory genes (CTLA4, CD69 and PD-L1) in severe psoriasis as compared to mild psoriasis, suggesting immune dysregulation as an important factor for disease progression [121]. Furthermore, the downregulation of negative immune regulators (FOXP3, CD69, FAS, CTLA4, PD-L1) have been identified in (Western) large plaque psoriasis as compared to (Asian) small plaque psoriasis, suggesting dysregulation of T-cells as a mechanism for expansion of psoriatic skin lesions [122]. Vitamin D has been identified to be an immunomodulator that primes differentiation of naïve $T$ cells into $T_{\text {Reg }}$ cells e.g. via antigen presentation by tolerogenic dendritic cells and inhibits activity of Th1 and Th17 cells [112, 123, 124]. The low serum levels of vitamin $\mathrm{D}$ in patients with psoriasis was associated with a decreased number of circulatory $T_{\text {Reg }}$ cells [112]. Therefore, authors suggested that a low level of vitamin D, found in patients with psoriasis, may impair immunological homeostasis, favoring Th1- and Th17-mediated inflammatory process [112, 125].

Photochemotherapy has been shown to increase the level of $T_{\text {Reg }}$ cells and enhance their suppressive function in patients with psoriasis [126]. Furthermore, treatment with biologics has been shown to reverse $T$ cells dysregulation in psoriasis $[127,128]$. Clinical response to etanercept may be associated with an upregulation of $T_{\text {Reg }}$ subsets and reversal of the Th1/Th17 activation [127]. Treatment with infliximab has been reported to increase polyclonality of $C D 4^{+}, C D 25^{+} T_{\text {Reg }}$ cells in patients with psoriasis [128]. Recently, it has been shown that calcipotriol and betamethasone dipropionate, acting synergistically normalize the balance between regulatory T cells and proinflammatory CCR $\sigma^{+} \gamma \delta$ Th17 cells, which contributes to the successful control of psoriasis in a murine psoriasis model [129]. Further, anti-IL-17A and antiIL-23p19 antibodies have been demonstrated to increase the number of $\mathrm{T}_{\text {Reg }}\left(\mathrm{Foxp}^{+}\right)$cells and IL-10 expression in a mouse model of imiquimod-induced psoriasiform dermatitis [130].

\section{Dysregulation of the skin neuroendocrine system}

The skin's capacity to coordinate complex responses to environmental stressors [131-134], as well as its ability to communicate with the central nervous (CNS), endocrine, and immune systems are well recognized [135-139]. These properties are facilitated by the local production of biogenic amines [140-144], melatonin [145, 146], corticotropin-releasing hormone $(\mathrm{CRH})$ and related urocortins [147-150], proopiomelanocortin (POMC)-derived peptides such as ACTH, $\beta$-endorphin, melanocyte stimulating peptides (MSH- $\alpha, \beta$ and $\gamma$ ) $[151,152]$, thyroid stimulating hormone (TSH), thyroid releasing hormone (TRH) and thyroid hormones [153, 154], enkephalins [155] and other neuropeptides [156-158], as well as cannabinoids [159], corticosteroids [160-167], and active forms of vitamin D [168-172] as examples. Production of these factors can be organized in local regulatory axes recapitulating hypothalamic-pituitary-adrenal (HPA) axis $[173,174]$ or hypothalamic-pituitary-thyroid axis [153, 154, 175, 176].

The dysregulation of the skin neuro-endocrine system, specifically of cutaneous HPA axis, can play a role in psoriasis, as well as inflammatory or autoimmune diseases $[139,177,178]$. For example, in the upper regulatory arm of the HPA, CRH has proinflammatory effects when synthesized in the peripheral tissues [179-187]. Accordingly, pathogenic roles for $\mathrm{CRH}$, related urocortin, and the corresponding CRHR1 receptor in psoriasis were also proposed [178, 188-194]. In addition, Vasiadi et al. [192] showed an increase in serum CRH levels with a simultaneous decrease in CRHR1 gene expression in psoriatic skin, while Loite et al. [195] showed an increased CRHR1 expression in psoriatic patients, accompanied by an increase in the level of POMC and MC2R. Cemil et al. [196] showed both an increased expression of CRHR1 protein with psoriasis and a positive correlation of PASI scores with CRHR1 expression. However, there was only one report [197] that showed the decreased levels of CRH and CRHR1 in chronic psoriasis. We also showed the deregulated $P O M C$ expression in inflammatory skin disorders, including psoriasis [198]. Thus, there is substantial evidence indicating disturbances in different elements of the cutaneous HPA axis in psoriasis [reviewed in 139, 199-201 and see above]. Furthermore, Hannen et al. [202] have not only shown that the executive arm of the HPA axis (glucocorticoid production and signaling) is defective in psoriatic skin, but also that key HPA axis regulators (CRH and POMC mRNA, CYP11A1 protein) are elevated in glucocorticoid receptor knockout mice compared to control mice. Although Sarkar et al. [203] provided strong evidence for deficient in situ synthesis of glucocorticoids (executive arm of the HPA), they contended that the cutaneous HPA axis was not defective. Since this was based on immunocytochemistry, this study showed an artificial nuclear immunostaining for "CRH" and its receptor "CRHR1" (possibly due to background staining from the secondary antibodies), as well as a lack of any other analytical method to measure proteins/peptide expression, such claim has not been found to be proven correct. In summary, the above reports demonstrate dysregulation of the cutaneous hypothalamic-pituitary arms of the HPA in a complex manner that requires further mechanistic studies. 


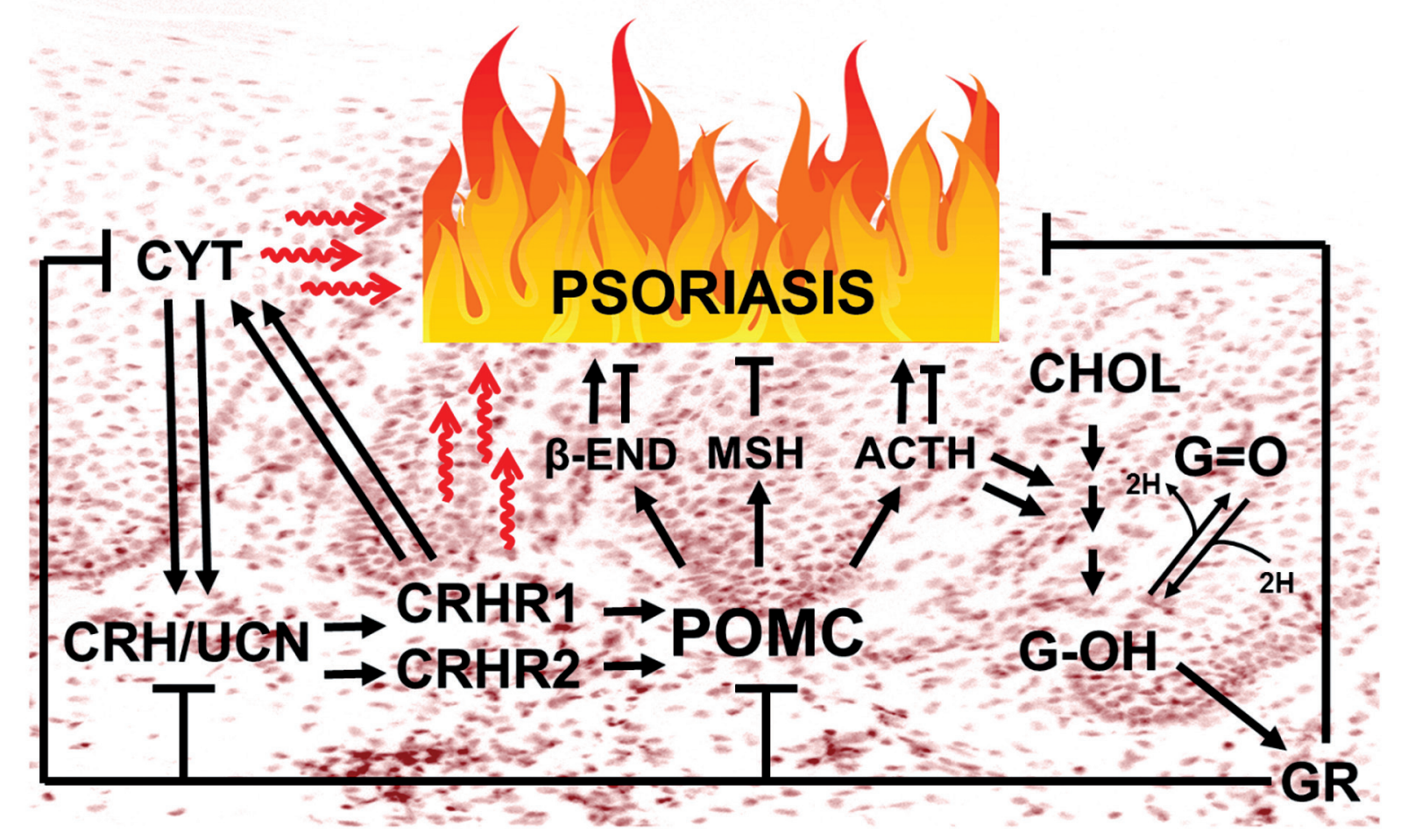

Figure 1. Modulated expression of the HPA axis elements underlies the development or aggravation of psoriasis. The immune-stimulatory activities of the upper arm of the cutaneous HPA axis are expected to be amplified by bidirectional communication between $\mathrm{CRH} /$ urocortin signaling and locally produced cytokines, unless attenuated by immune-inhibitory POMC peptides including ACTH, $\alpha$-MSH and $\beta$-endorphin (whose local production is stimulated by both CRH related peptides and/or selected cytokines) and/or terminated by glucocorticoids, which possibly serves as a counter-regulatory mechanism to avoid excessive inflammation

CYT - proinflammatory cytokines, CRH - corticotropin-releasing hormone, UCN - urocortins 1-3, CRHR1/CRHR2 - CRH receptor type 1 and 2, POMC - proopiomelanocortin, $\beta$-END - $\beta$-endorphin, MSH - melanocyte stimulating hormone, ACTH - adrenocorticotropic hormone, CHOL - cholesterol, G-OH - cortisol and corticosterone, G=O - cortisone and 11-dehydrocorticosterone, GR - glucocorticoid receptor (NR3C1).

It is important to revisit here the original concept of the cutaneous HPA axis [173] with a brief explanation of its likely role in psoriasis (Figure 1). In contrast to the central HPA, where all regulatory elements are anatomically separated and follow a linear structural hierarchy [204], in the skin all these elements are found at the same location, often within the same cells $[139,164,167]$. This may serve to secure a more evolutionarily conserved and nonlinear interactions within cellular compartments of human skin which are not possible in the central HPA axis [133, 167]. Consequently, $\mathrm{CRH}$ of hypothalamic origin will mainly induce a sequence of events which ultimately promotes a state of immunosuppression [204, 205], while CRH's direct action in peripheral tissues will primarily be proinflammatory/immunostimulatory [179] because of the dissociation from the central glucocorticoid signaling. Additionally, the direct activation of CRHR2 produces proinflammatory effects in peripheral tissues, at least in mice [206].

Again it is pertinent to recall some key aspects of this often misunderstood concept that cutaneous HPA axis controls key elements of human skin biology [139, 174, 207] and that it contributes to inflammatory skin diseases such as psoriasis $[178,202]$. In the skin, CRH and urocortin predominantly stimulate proinflammatory/immunostimulatory responses by either acting directly on normal keratinocytes [185] or through stimulation of cytokine production [186], or indirectly via mast cells activation [189, 190, 208-210]. Vice versa, proinflammatory cytokines are recognized as potent inducers of $\mathrm{CRH}$, urocortin and POMC both at the central and peripheral [139, 151, 211]. This proinflammatory cycle has to be terminated by downstream glucocorticoids, and by POMC-derived peptides including $\alpha-M S H$ and ACTH to restore local homeostasis $[139,167$, 212]. This termination of CRH/urocortin- or cytokineinduced proinflammatory activities can be mediated via indirect effects involving stimulation of POMC, the production and release of corticosteroids [160, 161, 164, 166], and POMC-peptides dependent downregulation of NF- $\kappa \beta$ activities in a context-dependent fashion [187, 213]. ACTH and $\beta$-endorphin, while predominantly acting as direct 
immunosuppressors [214-216], may have indirect immunostimulatory effects depending on the context [209, 216, 217], for example, via the activation of mast cells [202, 209]. For the other elements of the diffuse cutaneous-HPA axis which include the activities of $\mathrm{CRH}$-related peptides (urocortins 1-3), CRHR2, alternatively spliced CRHR1 and CRHR2 isoforms including membrane bound and soluble ones, and their coupling to different signal transduction systems, their precise roles in psoriasis remain to be established [139, 147, 150, 218-221].

In the absence of adequate cutaneous glucocorticoidmediated signaling [203, 204], the CRH and urocortin systems in psoriatic skin would have direct immunostimulatory and/or proinflammatory effects, including stimulation of local cytokine production and mast cell activation (Figure 1), as a part of a conserved protective system that defends the skin against biological, chemical and physical insults $[139,167]$. Within this cutaneous HPA system, immunomodulatory/immunosuppressive effects are mainly mediated by $\alpha-M S H, A C T H$ and by glucocorticoids, which also act as negative feed-back terminators of cytokine, CRH/urocortin and POMC-peptides production $[139,167]$ (Figure 1). Thus, a dysfunctional cutaneous HPA in psoriasis includes defects in the executive $(\mathrm{CRH}$ signaling) and feed-back terminating arms of the HPA, POMC peptides and glucocorticoid signaling systems.

This concept has clinical implications because the development of therapeutic strategies that normalize this dysregulated neuroendocrine axis in psoriatic skin may greatly improve psoriasis management. For example, restoring the intracutaneous production of POMC peptides or glucocorticoid production might help to spare the patient from anti-inflammatory pharmacotherapy, as well as curbing the post-steroid rebound phenomena seen in psoriasis. Thus, further investigation into the HPA axis activity in the skin of psoriatic patients could yield potentially novel treatment for psoriasis as well as other autoimmune skin diseases.

\section{Vascular changes, angiogenesis and endothelium dysfunction}

Psoriasis is also commonly associated with vascular modifications within cutaneous microcirculation [222, 223]. Initial changes are usually limited to the papillary dermis and appear long before epidermal hyperplasia can be detected. Typical features for psoriatic lesions include vascular network expansion and increased blood perfusion occurring together with morphological changes such as abnormally dilated, tortuous and elongated capillary loops [224]. Contrary to capillaries in healthy skin, they exert venous configuration characterized by the multilaminated basement membrane and bridge fenestration of the endothelial tube. This phenotype results in increased permeability facilitating the migration of serum proteins and inflammatory cells, which contributes significantly to the development of psoriatic plaques [225-230]. Vascular net expansion is a result of intense angiogenesis, where endothelial cells (ECs) sprout from existing blood vessels, migrate and proliferate to form new vessels. This process is strictly regulated by both pro- and antiangiogenic factors. Disturbed balance between those opposite groups of active molecules is a key element of increased pathological angiogenesis and development of psoriatic plaques [231-235].

Indeed, a significant number of studies revealed an increased level of proangiogenic compounds within psoriatic skin including hypoxia-inducible factor 1 (HIF-1), TNF- $\alpha$, TGF, endothelial cell stimulating angiogenesis factor (ESAF), platelet-derived growth factor (PDGF), IL-8, IL-17, angiopoietins and VEGF released mainly by activated basal keratinocytes [223, 231, 235-237]. These findings revealed a crucial role of interaction between keratinocytes and microvasculature within the skin in development of psoriasis. Another mechanism that plays an important role in angiogenesis is interaction of ECs with extracellular matrix. Increased expression of $\alpha v \beta 3$ integrin and adhesion molecules like E-selectin, vascular cell adhesion molecule-1 (VCAM-1) and intercellular adhesion molecule-1 (ICAM-1) was found within psoriatic skin lesions [226, 238].

One of the key growth factors regulating angiogenesis is VEGF $[239,240]$, which is produced by many cells including $T$ lymphocytes, monocytes, macrophages, fibroblasts, platelets, keratinocytes, smooth muscle cells, ECs, and tumor cells. VEGF participates in all stages of angiogenesis, under both physiological and pathological conditions; it stimulates proliferation and migration of ECs and formation of new vessels [241]. Increased levels of VEGF mRNA in keratinocytes isolated from skin of patients with psoriasis and an increased expression of its receptors, VEGFR-1 and VEGFR-2, in the endothelium of capillaries within the skin papillae from patients suffering from psoriasis were observed for the first time in 1994 [242]. VEGF expression is increased both in active psoriatic lesions and in unchanged skin of patients with psoriasis [241]. An increased amount of VEGF in psoriatic epidermal cells positively correlates with the severity of the disease. The important role of VEGF in development of psoriatic plaques was also confirmed with remission of psoriasis lesions during therapy with bevacizumab, a monoclonal antibody against VEGF $[243,244]$.

Neovascularization may also occur in a process termed postnatal vasculogenesis which contributes to circulating endothelial progenitor cells (CEPCS). CEPCs are a population of bone marrow-derived cells circulating in peripheral blood that have the ability to migrate, proliferate and differentiate into mature ECs. However, this particular mechanism of new blood vessel formation is unlikely to occur in psoriasis because the number of CEPCs in a serum of psoriatic patients is significantly declined [245]. 
In recent years a growing number of studies have revealed the association of psoriasis with other comorbidities, especially with cardiovascular diseases [231, 232, 234-246]. The risk of myocardial infarction and cerebrovascular disease is increased in psoriasis and correlates with disease severity. There is also an increased risk of coronary heart disease and atherosclerosis. Patients with psoriasis have increased carotid intima-media thickness, prevalence and severity of coronary artery calcification and atherosclerosis, and aortic vascular inflammation, all of which correlates positively with psoriasis severity [247251]. Most of the cardiovascular risk factors including hypertension, dyslipidemia, obesity, diabetes mellitus, and other metabolic pathologies are more prevalent in psoriasis [246, 251-253]. This association may be explained based on common pathogenic factors including inflammation and oxidative stress. The cytokine profile of psoriatic skin lesions and atherosclerotic vascular lesions show many similarities such as an increased number of Th1 and Th17 lymphocytes and Th17-related cytokines (IL-6, IL-8, IL-17). The systemic inflammation leads to adipose tissue inflammation and an increased release of proinflammatory adipokines such as leptin and resistin and a decreased level of anti-inflammatory adipokines that also protects against insulin resistance and atherogenesis. Psoriasis and atherosclerosis are also associated with similar reactive oxygen species signaling cascades including activation of the JAK-STAT, NF- $\kappa B$ and MAPK cascades [240, 248].

The combination of inflammation, oxidative stress and dyslipidemia leads to endothelial dysfunction. Patients with psoriasis present increased intima-media thickness (IMT) and stiffness of arteries combined with deteriorated vasodilation and decreased elasticity of vessels [254-257]. Patients with psoriasis revealed significantly increased carotid IMT, impaired endothelial function, and similar arterial stiffness compared to the control group [258]. In some studies flow mediated dilation (FMD) of the brachial artery was measured with ultrasound. FMD was significantly decreased comparing to the controls, which directly indicates dysfunction of endothelium [258, 259].

These findings are in agreement with studies revealing an increased number of circulating endothelial cells (CEC) and a decreased number of CEPCs in psoriatic patients $[245,260]$. The elevated number of CEC in psoriasis may be a result of both endothelium impairment and increased angiogenesis. CEPCs play a crucial role in maintenance of vascular homeostasis and regeneration of endothelium. As mentioned above, an impaired number and function of CEPCs have been found in patients with psoriasis. Both an increased number of CEC and a decreased number of CEPCs are considered as a marker of CVD risk.

Recently, a new approach linking psoriasis with AGE/ RAGE axis has emerged. AGEs are advanced glycation end products of non-enzymatic glycation between reducing sugars and free amino groups of proteins, lipids and nucleic acids. The most common modified residues are CML (N-carboxylmethyllysine), CEL (N-carboxylmethyllysine), pyrraline, pentosidine, $\mathrm{N}$-lactatolysine and imidazoles. AGEs are formed physiologically during aging but also accelerated levels of AGEs and RAGE (receptor for advanced glycation end products) are observed in many inflammatory and metabolic diseases like diabetes, atherosclerosis and also psoriasis. AGE accumulation in the skin leads to increased production of free radicals resulting in increased production of oxidized LDL and peroxidation products in the skin [261-263]. RAGE is a member of the superfamily of the immunoglobulins, multi-ligand signaling receptors. Beyond the AGES, RAGE binds certain members of the high mobility group box 1 (HMGB1) family, S100/calgranulin family, amyloid- $\beta$ peptide, $\beta$-sheet fibrils, lysophosphatidic acid, degraded extracellular matrix fragments and others. RAGE is also a transmembrane receptor expressed on the surface of many cells like ECs, monocytes, macrophages, smooth muscle cells, podocytes, astrocytes, DCs and epithelial cells like keratinocytes. Interaction between RAGE and its ligands leads to the activation of the transcription factor NF- $\mathrm{BB}$ that modulates transcription of inflammatory genes. RAGEmediated signaling triggers expression of adhesion molecules, proinflammatory cytokines and recruitment of inflammatory cells to the site of inflammation [263-265].

Within the inflamed psoriatic skin pronounced production of RAGE ligands - S100 proteins was also revealed, including psoriasin (S100A7) and koebnerisin (S100A15). Increased serum levels of Calgranulin A (S100A8), Calgranulin B (S100A9) and Calgranulin C (S100A12) were also observed in patients with psoriasis and correlated with the severity of skin involvement [261, 266]. HMGB1 level was increased in the serum of psoriatic patients. HMGB1 may favor the shift of T regulatory cells into Th17 cells playing a crucial role in psoriasis induction [267].

The elevated AGE level results in increased skin autofluorescence. Indeed, the level of skin autofluorescence was elevated in patients with severe psoriasis and correlates positively with the serum total AGE level and severity of disease [267]. Also, other studies implementing different techniques for AGEs concentration determination revealed an increased level of total AGEs, individual members of the AGE family, e.g. pentosidine, or even methylglyoxal - precursor of AGEs, in serum and skin of patients with psoriasis [256, 258, 267-269].

One of the RAGE isoforms is soluble RAGE (SRAGE) that is lacking a cytoplasmic tail and a domain crucial for signal transduction. sRAGE acts as a decoy receptor, binding RAGE ligands without mediation of any cellular activity [270]. However, in patients with psoriasis, serum levels of SRAGE are significantly lower comparing with controls and correlate inversely with disease severity. Decreased levels of sRAGE may contribute to the chronic inflammatory process and atherosclerosis. The SRAGE 
level may also be considered as a biomarker for disease severity and chronic inflammatory state in patients with psoriasis [261].

Interaction of RAGE with its ligands stabilizes the receptor in the active state amplifying inflammation by releasing of cytokines and chemokines, production of reactive oxygen species and the activation of metalloproteases. Inflammation is in turn associated with induction of more AGEs, enhancing the inflammatory response [262].

\section{Acknowledgments}

Partial support of NIH grants no. 1R01AR073004-01A1 and no. R01AR071189-01A1, grants of the Polish Ministry of Science and Higher Education Poland no. DIR/ WK/2017/01 and 02-0066/07/253, and by VA merit grant no. 1I01BX004293-01A1 to ATS is acknowledged.

\section{Conflict of interest}

The authors declare no conflict of interest.

\section{References}

1. WHO. Global report on psoriasis. Geneva: World Health Organization, 2016.

2. https://globalpsoriasisatlas.org/statistics/prevalence

3. Parisi R, Symmons DP, Griffith CE, et al. Global epidemiology of psoriasis: a systemic review of incidence and prevalence. J Invest Dermatol 2013; 133: 377-85.

4. Rachakonda TD, Schupp CW, Armstrong AW. Psoriasis prevalence among adults in the United States. J Am Acad Dermatol 2014; 70: 512-6.

5. Michalek IM, Loring B, John SM. A systematic review of worldwide epidemiology of psoriasis. J Eur Acad Dermatol Venereol 2017; 31: 205-12.

6. Borzęcki A, Koncewicz A, Raszewska-Famielec M, et al. Epidemiology of psoriasis in the years 2008-2015. Przegl Dermatol 2018; 105: 693-700.

7. Henseler T, Christophers E. Psoriasis of early and late onset: characterization of two types of psoriasis vulgaris. J Am Acad Dermatol 1985; 13: 450-6.

8. Adamiak M, Tokarz-Deptuła B, Deptuła W. Characteristic of innate lymphoid cells (ILC). Postep Hig Med Dosw 2014; 68: 1464-71.

9. Yazdani R, Sharifi M, Shirvan AS, et al. Characteristics of innate lymphoid cells (ILCS) and their role in immunological disorders (an update). Cell Immunol 2015; 298: 66-76.

10. Chiricozzi A, Romanelli P, Volpe E, et al. Scanning the immunopathogenesis of psoriasis. Int J Mol Sci 2018; 19: pii: E179.

11. Tsai YC, Tsai TF. Anti-interleukin and interleukin therapies for psoriasis: current evidence and clinical usefulness. Ther Adv Musculoskel Dis 2017; 9: 277-94.

12. Nedoszytko B, Roszkiewicz J. The role of the subpopulations od dendritic cells in psoriasis. Post Dermatol Alergol 2007; 24: 263-70.

13. Wang AO, Bai YP. Dendritic cells: the driver of psoriasis. J Dermatol 2020; 47: 104-13.

14. Zawadzka A, Lange M, Nedoszytko B, et al. Mast cells and their role in pathogenesis of selected skin diseases. Forum Derm 2016; 2: 12-9.
15. Conti P, Gallenga CE, Ronconi G, et al. Activation of mast cells mediates inflammatory response in psoriasis: potential new therapeutic approach with IL-37. Dermatol Ther 2019; 32: e12943.

16. Theoharides TC, Alysandratos KD, Angelidou A, et al. Mast cells and inflammation. Biochim Biophys Acta 2012; 1822: 21-33.

17. Geissmann F, Manz MG, Jung S, et al. Development of monocytes, macrophages and dendritic cells. Science 2010; 327: 656-61.

18. Behfar SH, Hassanshahi G, Nazari A, Khorramdelazad H. A brief look at the role of monocyte chemoattractant protein-1 (CCL2) in pathophysiology of psoriasis. Cytokine 2018; 110: 226-31.

19. Mahil SK, Capon F, Barker JN. Update on psoriasis immunopathogenesis and targeted immunotherapy. Semin Immunopathol 2016; 38: 11-27.

20. Błażewicz I, Jaśkiewicz M, Piechowicz L, et al. The role of antimicrobial peptides in selected dermatoses. Przegl Dermatol 2016; 103: 227-32.

21. Kim J, Krueger JG. The immunopathogenesis of psoriasis. Dermatol Clin 2015; 33: 13-23.

22. Vivier E, Tomasello E, Baratin M, et al. Functions of natural killer cells. Nat Immunol 2008; 9: 503-10.

23. Bojarska-Junak A, Tombarkiewicz J, Roliński J. NKT cells: their development, mechanisms and effects of action. Post Hig Med Dosw 2013; 67: 65-78.

24. Cai Y, Shen $X$, Ding C, et al. Pivotal role of dermal IL-17-producing gammadelta $T$ cells in skin inflammation. Immunity 2011; 35: 596-610.

25. Di Cesare A, Di Meglio P, Nestle FO. The IL-23/Th17 axis in the immunopathogenesis of psoriasis. J Invest Dermatol 2009; 129: 1339-50.

26. Rønholt K, Iversen L. Old and new biological therapies for psoriasis. Int J Mol Sci 2017; 18: 2297.

27. Johansen C, Usher PA, Kjellerup RB, et al. Characterization of the interleukin-17 isoforms and receptors in lesional psoriatic skin. Br J Dermatol 2009; 160: 319-24.

28. Kagami S, Rizzo HL, Lee JJ, et al. Circulating Th17, Th22, and Th1 cells are increased in psoriasis. J Investig Dermatol 2010; 130: 1373-83.

29. Nestle FO, Di Meglio P, Qin JZ, et al. Skin immune sentinels in health and disease. Nat Rev Immunol 2009; 9: 679-91.

30. Lowes MA, Suárez-Farińas M, Krueger JG. Immunology of psoriasis. Annu Rev Immunol 2014; 32: 227-55.

31. Wollenberg A, Wagner M, Gunther S, et al. Plasmacytoid dendritic cells: a new cutaneous dendritic cell subset with distinct role in inflammatory skin diseases. I Invest Dermatol 2002; 119: 1096-102.

32. Gilliet M, Conrad C, Geiges M, et al. Psoriasis triggered by toll-like receptor 7 agonist imiquimod in the presence of dermal plasmacytoid dendritic cell precursors. Arch Dermatol 2004; 140: 1490-5.

33. Nestle FO, Conrad C, Tun-Kyi A, et al. Plasmacytoid predendritic cells initiate psoriasis through interferon-alpha production. J Exp Med 2005; 202: 135-43.

34. Lande R, Gregorio J, Facchinetti V, et al. Plasmacytoid dendritic cells sense self-DNA coupled with antimicrobial peptide. Nature 2007; 449: 564-9.

35. Blasius AL, Beutler B. Intracellular toll-like receptors. Immunity 2010; 32: 305-15.

36. Morizane S, Gallo RL. Antimicrobial peptides in the pathogenesis of psoriasis. J Dermatol 2012; 39: 225-30. 
37. Kahlenberg JM, Kaplan MJ. Little peptide, big effects: the role of LL-37 in inflammation and autoimmune disease. J Immunol 2013; 191: 4895-901.

38. Ganguly D, Chamilos G, Lande R, et al. Self-RNA-antimicrobial peptide complexes activate human dendritic cells through TLR7 and TLR8. J Exp Med 2009; 206: 1983-94

39. Chamilos G, Gregorio J, Meller S, et al. Cytosolic sensing of extracellular self-DNA transported into monocytes by the antimicrobial peptide LL37. Blood 2012; 120: 3699-707.

40. Morizane S, Yamasaki K, Mühleisen B, et al. Cathelicidin antimicrobial peptide LL-37 in psoriasis enables keratinocyte reactivity against TLR9 ligands. I Invest Dermatol 2012; 132: 135-43.

41. Lai CY, Su YW, Lin KI, et al. Natural modulators of endosomal Toll-like receptor-mediated psoriatic skin inflammation. J Immunol Res 2017; 2017: 7807313.

42. Lande R, Botti E, Jandus C, et al. The antimicrobial peptide LL37 is a T-cell autoantigen in psoriasis. Nat Commun 2014; 5: 5621.

43. Dienz O, Rincon M. The effects of IL-6 on CD4 T cell responses. Clin Immunol 2009; 130: 27-33.

44. Cai Y, Fleming C, Yan J. New insights of T cells in the pathogenesis of psoriasis. Cell Mol Immunol 2012; 9: 302-9.

45. Benham H, Norris P, Goodall J, et al. Th17 and Th22 cells in psoriatic arthritis and psoriasis. Arthritis Res Ther 2013; 15: R136.

46. Hegyi Z, Zwicker S, Bureik D, et al. Vitamin D analog calcipotriol suppresses the Th17 cytokine-induced proinflammatory S100 "alarmins" psoriasin (S100A7) and koebnerisin (S100A15) in psoriasis. J Invest Dermatol 2012; 132: 1416-24.

47. Nedoszytko B, Sokołowska-Wojdyło M, RuckemannDziurdzińska K, et al. Chemokines and cytokines network in the pathogenesis of the inflammatory skin diseases: atopic dermatitis, psoriasis and skin mastocytosis. Adv Dermatol Alergol 2014; 31: 84-91.

48. Georgescu SR, Tampa M, Caruntu C, et al. Advances in understanding the immunological pathways in psoriasis. Int J Mol Sci 2019; 20: pii: E739.

49. Kolls JK, Linden A. Interleukin-17 family members and inflammation. Immunity 2004; 21: 467-76.

50. Ishigame H, Kakuta S, Nagai T, et al. Differential roles of interleukin-17A and -17F in host defense against mucoepithelial bacterial infection and allergic responses. Immunity 2009; 30: 108-19.

51. Meller S, Di Domizio J, Voo KS, et al. Th17 cells promote microbial killing and innate immune sensing of DNA via interleukin 26. Nat Immunol 2015; 16: 970-9.

52. Blauvelt A, Chiricozzi A. The immunologic role of IL-17 in psoriasis and psoriatic arthritis pathogenesis. Clin Rev Allergy Immunol 2018; 55: 379-90.

53. Zaba LC, Cardinale I, Gilleaudeau P, et al. Amelioration of epidermal hyperplasia by TNF inhibition is associated with reduced Th17 responses. J Exp Med 2007; 204: 3183-94.

54. Senra L, Stalder R, Alvarez Martinez D, et al. Keratinocytederived IL-17E contributes to inflammation in psoriasis. J Invest Dermatol 2016; 136: 1970-80.

55. Michel ML, Keller AC, Paget C, et al. Identification of an IL17-producing NK1.1(neg) iNKT cell population involved in airway neutrophilia. J Exp Med 2007; 204: 995-1001.

56. Doisne JM, Becourt C, Amniai L, et al. Skin and peripheral lymph node invariant NKT cells are mainly retinoic acid receptor-related orphan receptor (gamma)t+ and respond preferentially under inflammatory conditions. J Immunol 2009; 183: 2142-9.

57. Lin AM, Rubin CJ, Khandpur R, et al. Mast cells and neutrophils release IL-17 through extracellular trap formation in psoriasis. J Immunol 2011; 187: 490-500.
58. Ouyang W, Kolls JK, Zheng Y. The biological functions of Thelper 17 cell effector cytokines in inflammation. Immunity 2008; 28: 454-67.

59. Yao Z, Fanslow WC, Seldin MF, et al. Herpesvirus Saimiri encodes a new cytokine, IL-17, which binds to a novel cytokine receptor. Immunity 1995; 3: 811-21.

60. Gaffen SL. Structure and signalling in the IL-17 receptor family. Nat Rev Immunol 2009; 9: 556-567.

61. Gu C, Wu L, Li X. IL-17 family: cytokines, receptors and signaling. Cytokine 2013; 64: 477-85.

62. Chiricozzi A, Guttman-Yassky E, Suarez-Farinas M, et al. Integrative responses to IL-17 and TNF-alpha in human keratinocytes account for key inflammatory pathogenic circuits in psoriasis. J Invest Dermatol 2011; 131: 677-87.

63. Ha HL, Wang H, Pisitkun P, et al. IL-17 drives psoriatic inflammation via distinct, target cell-specific mechanisms. Proc Natl Acad Sci USA 2014 19; 111: E3422-31.

64. Adami S, Cavani A, Rossi F, Girolomoni G. The role of interleukin-17A in psoriatic disease. Bio Drugs 2014; 28: 487-97.

65. Oppmann B, Lesley R, Blom B, et al. Novel p19 protein engages IL-12p40 to form a cytokine, IL-23, with biological activities similar as well as distinct from IL-12. Immunity 2000; 13: 715-25.

66. Girolomoni G, Strohal R, Puig L, et al. The role of IL-23 and the IL-23/Th 17 immune axis in the pathogenesis and treatment of psoriasis. J Eur Acad Dermatol Venereol 2017; 31: 1616-26.

67. Lyakh L, Trinchieri G, Provezza L, et al. Regulation of interleukin-12/interleukin-23 production and the T-helper 17 response in humans. Immunol Rev 2008; 226: 112-31.

68. Langrish CL, Chen Y, Blumenschein WM, et al. IL-23 drives a pathogenic $T$ cell population that induces autoimmune inflammation. J Exp Med 2005; 201: 233-40.

69. Parham C, Chirica M, Timans J, et al. A receptor for the heterodimeric cytokine IL-23 is composed of IL-12Rbeta1 and a novel cytokine receptor subunit, IL-23R. J. Immunol 2002; 168: 5699-708.

70. Teng MW, Bowman EP, McElwee JJ, et al. IL-12 and IL-23 cytokines: from discovery to targeted therapies for immunemediated inflammatory diseases. Nat Med 2015; 21: 719-29.

71. Awasthi A, Riol-Blanco L, Jager A, et al. Cutting edge: IL-23 receptor gfp reporter mice reveal distinct populations of IL17-producingcells. J Immunol 2009; 182: 5904-8.

72. Sano S, Chan KS, DiGiovanni J. Impact of Stat3 activation upon skin biology: a dichotomy of its role between homeostasis and diseases. J Dermatol Sci 2008; 50: 1-14.

73. Stritesky GL, Yeh N, Kaplan MH. IL-23 promotes maintenance but not commitment to the Th17 lineage. J Immunol 2008; 181: 5948-55.

74. Aggarwal S, Ghilardi N, Xie MH, et al. Interleukin-23 promotes a distinct CD4 T cell activation state characterized by the production of interleukin-17. J Biol Chem 2003; 278: 1910-4.

75. Mangan PR, Harrington LE, O'Quinn DB, et al. Transforming growth factor-beta induces development of the Th17 lineage. Nature 2006; 441: 231-4.

76. Ivanov II, McKenzie BS, Zhou L, et al. The orphan nuclear receptor RORgammat directs the differentiation program of proinflammatory IL-17+ T helper cells. Cell 2006; 126: 1121-33.

77. Louten J, Boniface K, de Waal Malefyt R. Development and function of Th17 cells in health and disease. J Allergy Clin Immunol 2009; 123: 1004-11.

78. Korn T, Bettelli E, Gao W, et al. IL-21 initiates an alternative pathway to induce proinflammatory Th17 cells. Nature 2007; 448: 484-7. 
79. Chaudhari U, Romano P, Mulcahy LD, et al. Efficacy and safety of infliximab monotherapy for plaque-type psoriasis: a randomized trial. Lancet 2001; 357: 1842-7.

80. Ettehadi P, Greaves MW, Wallach D, et al. Elevated tumour necrosis factor-alpha (TNF alpha) biological activity in psoriatic skin lesions. Clin Exp Immunol 1994; 96: 146-51.

81. Bonifati C, Carducci M, Cordiali Fei P, et al. Correlated increases of tumour necrosis factor-alpha, interleukin- 6 and granulocyte monocyte-colony stimulating factor levels in suction blister fluids and sera of psoriatic patients - relationships with disease severity. Clin Exp Dermatol 1994; 19: 383-7.

82. Mussi A, Bonifati C, Carducci M, et al. Serum TNF alpha levels correlate with disease severity and are reduced by effective therapy in plaque-type psoriasis. J Biol Regul Homeost Agents 1997; 11: 115-8.

83. Arican O, Aral M, Sasmaz S, Ciragil P. Serum levels of TNFalpha, IFN-gamma, IL-6, IL-8, IL-12, IL-17, and IL-18 in patients with active psoriasis and correlation with disease severity. Mediators Inflamm 2005; 2005: 273-9.

84. Abanmi A, Al Harthi F, Al Agla R, et al. Serum levels of proinflammatory cytokines in psoriasis patients from Saudi Arabia. Int J Dermatol 2005; 44: 82-3.

85. Wakefield PE, James WD, Samlaska CP, Meltzer MS. Tumor necrosis factor. J Am Acad Dermatol 1991; 24: 675-85.

86. Kristensen M, Chu CQ, Eedy DJ, et al. Localization of tumour necrosis factor-alpha (TNF-alpha) and its receptors in normal and psoriatic skin: epidermal cells express the 55-kD but not the 75-kD TNF receptor. Clin Exp Immunol 1993; 94: 354-62.

87. Zaba LC, Fuentes-Duculan J, Eungdamrong NJ, et al. Psoriasis is characterized by accumulation of immunostimulatory and Th1/Th17 cell-polarizing myeloid dendritic cells. J Invest Dermatol 2009; 129: 79-88.

88. Tsuruta D. NF-kappa B links keratinocytes and lymphocytes in the pathogenesis of psoriasis. Recent Pat Inflamm Allergy Drug Discov 2009; 3: 40-8.

89. Gottlieb AB, Chamian F, Masud S, et al. TNF inhibition rapidly down-regulates multiple proinflammatory pathways in psoriasis plaques. J Immunol 2005; 175: 2721-9.

90. Oh H, Ghosh S. NF-kappaB: roles and regulation in different CD4(+) T-cell subsets. Immunol Rev 2013; 252: 41-51.

91. Wolk K, Kunz S, Witte E, et al. IL-22 increases the innate immunity of tissues. Immunity 2004; 21: 241-54.

92. Chen SC, de Groot M, Kinsley D, et al. Expression of chemokine receptor CXCR3 by lymphocytes and plasmacytoid dendritic cells in human psoriatic lesions. Arch Dermatol Res 2010; 302: 113-23.

93. Duhen T, Geiger R, Jarrossay D, et al. Production of interleukin 22 but not interleukin 17 by a subset of human skinhoming memory T cells. Nat Immunol 2009; 10: 857-63.

94. Jia L, Wu C. The biology and functions of Th22 cells. Adv Exp Med Biol 2014; 841: 209-30.

95. Dudakov JA, Hanash AM, van den Brink MR. Interleukin-22: immunobiology and pathology. Annu Rev Immunol 2015; 33: 747-85.

96. Mashiko S, Bouguermouh S, Rubio M, et al. Human mast cells are major IL-22 producers in patients with psoriasis and atopic dermatitis. J Allergy Clin Immunol 2015; 136: 351-9.e1.

97. Kotenko SV, Izotova LS, Mirochnitchenko OV, et al. Identification of the functional interleukin-22 (IL-22) receptor complex: the IL-10R2 chain (IL-10Rbeta) is a common chain of both the IL-10 and IL-22 (IL-10-related T cell-derived in- ducible factor, IL-TIF) receptor complexes. J Biol Chem 2001; 276: $2725-32$

98. Lejeune D, Dumoutier L, Constantinescu S, et al. Interleukin-22 (IL-22) activates the JAK/STAT, ERK, JNK, and p38 MAP kinase pathways in a rat hepatoma cell line. Pathways that are shared with and distinct from IL-10. J Biol Chem 2002; 277: 33676-82

99. Zhang W, Dang E, Shi X, et al. The pro-inflammatory cytokine IL-22 up-regulates keratin 17 expression in keratinocytes via STAT3 and ERK1/2. PLOS One 2012; 7: e40797.

100. Yang X, Zheng SG. Interleukin-22: a likely target for treatment of autoimmune diseases. Autoimmun Rev 2014; 13: 615-20.

101. Zenewicz LA. IL-22: there is a gap in our knowledge. Immunohorizons 2018; 2: 198-207.

102. Wawrzycki B, Pietrzak A, Grywalska E, et al. Interleukin-22 and its correlation with disease activity in plaque psoriasis. Arch Immunol Ther Exp 2019; 67: 103-8.

103. NIH. U.S. National Library of Medicine. Clinical Trials. Available online: ClinicalTrials.gov identifier: NCT00563524.

104. Buckner JH. Mechanisms of impaired regulation by CD4(+) CD25(+)FOXP3(+) regulatory T cells in human autoimmune diseases. Nat Rev Immunol 2010; 10: 849-59.

105. Nedoszytko B, Lange M, Sokołowska-Wojdyło M, et al. The role of regulatory $T$ cells and genes involved in their differentiation in pathogenesis of selected inflammatory and neoplastic skin diseases. Part II: the Treg role in skin diseases pathogenesis. Adv Dermatol Allergol 2017; 34: 405-17.

106. Zhang L, Yang XQ, Cheng J, et al. Increased Th17 cells are accompanied by FoxP3(+) Treg cell accumulation and correlated with psoriasis disease severity. Clin Immunol 2010; 135: 108-17.

107. Fujimura T, Okuyama R, Ito Y, et al. Profiles of Foxp3+ regulatory $T$ cells in eczematous dermatitis, psoriasis vulgaris and mycosis fungoides. Br J Dermatol 2008; 158: 1256-63.

108. Chen L, Shen Z, Wang G, et al. Dynamic frequency of CD4+CD25+Foxp3+Treg cells in psoriasis vulgaris. J Dermatol Sci 2008; 51: 200-3.

109. Yan KX, Fang X, Han L, et al. Foxp3+ regulatory T cells and related cytokines differentially expressed in plaque vs. guttate psoriasis vulgaris. Br J Dermatol 2010; 163: 48-56.

110. Pawlaczyk M, Karczewski J, Wiktorowicz K. T regulatory CD4+CD25high lymphocytes in peripheral blood of patients suffering from psoriasis. Adv Dermatol Allergol 2010; 27: 25-8.

111. Yun WJ, Lee DW, Chang SE, et al. Role of CD4CD25FOXP3 regulatory T cells in psoriasis. Ann Dermatol 2010; 22: 397-403.

112. Mattozzi C, Paolino G, Salvi M, et al. Peripheral blood regulatory $T$ cell measurements correlate with serum vitamin D level in patients with psoriasis. Eur Rev Med Pharmacol Sci 2016; 20: 1675-9.

113. Sugiyama H, Gyulai R, Toichi E, et al. Dysfunctional blond and target tissue CD4+CD25high regulatory T cells in psoriasis: mechanism underlying unrestrained pathogenic effector T cell proliferation. J Immunol 2005; 174: 164-73.

114. Zhang K, Li X, Yin G, et al. Functional characterization of CD4+CD25+ regulatory $T$ cells differentiated in vitro from bone marrow-derived haematopoietic cells of psoriasis patients with a family history of the disorder. Br J Dermatol 2008; 158: 298-305.

115. Goodman WA, Levine AD, Massari JV, et al. IL-6 signaling in psoriasis prevents immune suppression by regulatory T cells. J Immunol 2009; 183: 3170-6. 
116. Bovenschen HJ, van Vlijmen-Willems IM, van de Kerkhof PC, et al. Foxp3+ regulatory T cells of psoriasis patients easily differentiate into IL-17A-producing cells and are found in lesional skin. J Invest Dermatol 2011; 131: 1853-60.

117. Soler DC, McCormick TS. The dark side of regulatory T cells in psoriasis. J Invest Dermatol 2011; 131: 1785-6.

118. Kannan AK, Su Z, Gauvin DM, et al. IL-23 induces regulatory $T$ cell plasticity with implications for inflammatory skin diseases. Sci Rep 2019; 9: 17675.

119. Zhao M, Wang LT, Liang GP, et al. Up-regulation of microRNA-210 induces immune dysfunction via targeting FOXP3 in CD4(+) T cells of psoriasis vulgaris. Clin Immunol 2014; 150: $22-30$

120. Keijsers RR, van der Velden HM, van Erp PE, et al. Balance of Treg vs. T-helper cells in the transition from symptom less to lesional psoriatic skin. Br J Dermatol 2013; 168: 1294-302.

121. Kim J, Bissonnette R, Lee J, et al. The spectrum of mild to severe psoriasis vulgaris is defined by a common activation of IL-17 pathway genes, but with key differences in immune regulatory genes. J Invest Dermatol 2016; 136: 2173-82.

122. Kim J, Oh CH, Jeon J, et al. Molecular phenotyping small (Asian) versus large (Western) plaque psoriasis show common activation of IL-17 pathway genes but different regulatory gene sets. J Invest Dermatol 2016; 136: 161-72.

123. Chambers ES, Hawrylowicz CM. The impact of vitamin D on regulatory T cells. Curr Allergy Asthma Rep 2011; 11: 29-36.

124. Adorini L. Tolerogenic dendritic cells induced by vitamin D receptor ligands enhance regulatory $T$ cells inhibiting autoimmune diabetes. Ann N Y Acad Sci 2003; 987: 258-61.

125. Orgaz-Molina J, Buendia-Eisman A, Arrabal-Polo MA, et al. Deficiency of serum concentration of 25-hydroxyvitamin D in psoriatic patients: a case-control study. J Am Acad Dermatol 2012; 67: 931-8.

126. Furuhashi T, Saito C, Torii K, et al. Photo(chemo)therapy reduces circulating Th17 cells and restores circulating regulatory T cells in psoriasis. PLoS One 2013; 8: e54895.

127. Quaglino P, Bergallo M, Ponti R, et al. Th1, Th2, Th17 and regulatory $T$ cell pattern in psoriatic patients: modulation of cytokines and gene targets induced by etanercept treatment and correlation with clinical response. Dermatology 2011; 223: 57-67.

128. Diluvio L, Romiti ML, Angelini F, et al. Infliximab therapy induces increased polyclonality of CD4+CD25+ regulatory T cells in psoriasis. Br J Dermatol 2010; 162: 895-7.

129. Satake K, Amano T, Okamoto T. Calcipotriol and betamethasone dipropionate synergistically enhances the balance between regulatory and proinflammatory $T$ cells in a murine psoriasis model. Sci Rep 2019; 9: 16322.

130. Shimizu T, Kamata M, Fukaya S, et al. Anti-IL-17A and IL23 p19 antibodies but not anti-TNFalpha antibody induce expansion of regulatory $T$ cells and restoration of their suppressive function in imiquimod-induced psoriasiform dermatitis. J Dermatol Sci 2019; 95: 90-8.

131. Slominski A, Wortsman J. Neuroendocrinology of the skin. Endocr Rev 2000; 21: 457-87.

132. Slominski AT, Zmijewski MA, Skobowiat C, et al. Sensing the environment: regulation of local and global homeostasis by the skin's neuroendocrine system. Adv Anat Embryol Cell Biol 2012; 212: 1-115.

133. Slominski AT, Manna PR, Tuckey RC. On the role of skin in the regulation of local and systemic steroidogenic activities. Steroids 2015; 103: 72-88.
134. Slominski AT, Zmijewski MA, Plonka PM, et al. How UV light touches the brain and endocrine system through skin, and why. Endocrinology 2018; 159: 1992-2007.

135. Skobowiat C, Postlethwaite AE, Slominski AT. Skin exposure to ultraviolet $B$ rapidly activates systemic neuroendocrine and immunosuppressive responses. Photochem Photobiol 2017; 93: 1008-15.

136. Skobowiat C, Slominski AT. Ultraviolet B stimulates proopiomelanocortin signalling in the arcuate nucleus of the hypothalamus in mice. Exp Dermatol 2016; 25: 120-3.

137. Skobowiat C, Slominski AT. UVB activates hypothalamicpituitary-adrenal axis in C57BL/6 Mice. J Invest Dermatol 2015; 135: 1638-48.

138. Slominski AT. Ultraviolet radiation (UVR) activates central neuro-endocrine-immune system. Photodermatol Photoimmunol Photomed 2015; 31: 121-3.

139. Slominski AT, Zmijewski MA, Zbytek B, et al. Key role of CRF in the skin stress response system. Endocr Rev 2013; 34: 827-84.

140. Schallreuter KU, Wood JM, Pittelkow MR, et al. Regulation of melanin biosynthesis in the human epidermis by tetrahydrobiopterin. Science 1994; 263: 1444-6.

141. Schallreuter KU, Lemke KR, Pittelkow MR, et al. Catecholamines in human keratinocyte differentiation. J Invest Dermatol 1995; 104: 953-7.

142. Slominski A, Pisarchik A, Semak I, et al. Serotoninergic system in hamster skin. J Invest Dermatol 2002; 119: 934-42.

143. Slominski A, Pisarchik A, Semak I, et al. Serotoninergic and melatoninergic systems are fully expressed in human skin. FASEB J 2002; 16: 896-8.

144. Slominski A, Wortsman J, Tobin DJ. The cutaneous serotoninergic/melatoninergic system: securing a place under the sun. FASEB J 2005; 19: 176-94.

145. Slominski AT, Zmijewski MA, Semak I, et al. Melatonin, mitochondria, and the skin. Cell Mol Life Sci 2017; 74: 3913-25.

146. Slominski AT, Hardeland R, Zmijewski MA, et al. Melatonin: a cutaneous perspective on its production, metabolism, and functions. J Invest Dermatol 2018; 138: 490-9.

147. Slominski A, Roloff B, Curry J, et al. The skin produces urocortin. J Clin Endocrinol Metab 2000; 85: 815-23.

148. Slominski A, Szczesniewski A, Wortsman J. Liquid chromatography-mass spectrometry detection of corticotropin-releasing hormone and proopiomelanocortin-derived peptides in human skin. J Clin Endocrinol Metab 2000; 85: 3582-8.

149. Slominski, A, Ermak G, Mazurkiewicz JE, et al. Characterization of corticotropin-releasing hormone (CRH) in human skin. J Clin Endocrinol Metab 1998; 83: 1020-4.

150. Slominski A, Pisarchik A, Tobin DJ, et al. Differential expression of a cutaneous corticotropin-releasing hormone system. Endocrinology 2004; 145: 941-50.

151. Slominski A, Wortsman J, Luger T, et al. Corticotropin releasing hormone and proopiomelanocortin involvement in the cutaneous response to stress. Physiol Rev 2000; 80: 979-1020.

152. Slominski A, Tobin DJ, Shibahara S, Wortsman J. Melanin pigmentation in mammalian skin and its hormonal regulation. Physiol Rev 2004; 84: 1155-228.

153. Slominski A, Wortsman J, Kohn L, et al. Expression of hypothalamic-pituitary-thyroid axis related genes in the human skin. J Invest Dermatol 2002; 119: 1449-55.

154. van Beek N, Bodó E, Kromminga A, et al. Thyroid hormones directly alter human hair follicle functions: anagen prolongation and stimulation of both hair matrix keratinocyte 
proliferation and hair pigmentation. J Clin Endocrinol Metab 2008; 93: 4381-8.

155. Slominski AT, Zmijewski MA, Zbytek B, et al. Regulated proenkephalin expression in human skin and cultured skin cells. J Invest Dermatol 2011; 131: 613-22.

156. Botchkarev VA, Yaar M, Peters EM, et al. Neurotrophins in skin biology and pathology. J Invest Dermatol 2006; 126: 1719-27.

157. Paus R, Schmelz M, Bíró T, Steinhoff M. Frontiers in pruritus research: scratching the brain for more effective itch therapy. J Clin Invest 2006; 116: 1174-86.

158. Paus R, Theoharides TC, Arck PC. Neuroimmunoendocrine circuitry of the 'brain-skin connection'. Trends Immunol 2006; 27: 32-9.

159. Biro T, Tóth Bl, Haskó G, et al. The endocannabinoid system of the skin in health and disease: novel perspectives and therapeutic opportunities. Trends Pharmacol Sci 2009; 30: 411-20.

160. Slominski A, Zbytek B, Semak I, et al. CRH stimulates POMC activity and corticosterone production in dermal fibroblasts. J Neuroimmunol 2005; 162: 97-102.

161. Slominski A, Zbytek B, Szczesniewski A, et al. CRH stimulation of corticosteroids production in melanocytes is mediated by ACTH. Am J Physiol Endocrinol Metab 2005; 288: E701-6.

162. Slominski A, Zjawiony J, Wortsman J, et al. A novel pathway for sequential transformation of 7-dehydrocholesterol and expression of the P450scc system in mammalian skin. Eur J Biochem 2004; 271: 4178-88.

163. Slominski A, Zbytek B, Szczesniewski A, Wortsman J. Cultured human dermal fibroblasts do produce cortisol. J Invest Dermatol 2006; 126: 1177-8.

164. Ito N, Ito T, Kromminga A, et al. Human hair follicles display a functional equivalent of the hypothalamic-pituitary-adrenal axis and synthesize cortisol. FASEB J 2005; 19: 1332-4.

165. Skobowiat C, Dowdy JC, Sayre RM, et al. Cutaneous hypothalamic-pituitary-adrenal axis homolog: regulation by ultraviolet radiation. Am J Physiol Endocrinol Metab 2011; 301: E484-93.

166. Vukelic S, Stojadinovic O, Pastar I, et al. Cortisol synthesis in epidermis is induced by IL-1 and tissue injury. J Biol Chem 2011; 286: 10265-75.

167. Slominski A. A nervous breakdown in the skin: stress and the epidermal barrier. J Clin Invest 2007; 117: 3166-9.

168. Holick MF. Vitamin D: a millennium perspective. J Cell Biochem 2003; 88: 296-307.

169. Bikle DD. Vitamin D and the skin: physiology and pathophysiology. Rev Endocr Metab Disord 2012; 13: 3-19.

170. Slominski AT, Kim TK, Li W, et al. The role of CYP11A1 in the production of vitamin $D$ metabolites and their role in the regulation of epidermal functions. J Steroid Biochem $\mathrm{Mol}$ Biol 2014; 144: 28-39.

171. Skobowiat C, Sayre RM, Dowdy JC, Slominski AT. Ultraviolet radiation regulates cortisol activity in a waveband-dependent manner in human skin ex vivo. Br J Dermatol 2013; 168: 595-601.

172. Slominski A, Zbytek B, Nikolakis G, et al. Steroidogenesis in the skin: implications for local immune functions. J Steroid Biochem Mol Biol 2013; 137: 107-23.

173. Slominski A, Mihm MC. Potential mechanism of skin response to stress. Int J Dermatol 1996; 35: 849-51.

174. Slominski A, Wortsman J, Tuckey RC, Paus R. Differential expression of HPA axis homolog in the skin. Mol Cell Endocrinol 2007; 265-266: 143-9.
175. Bodo E, Kromminga A, Bíró T, et al. Human female hair follicles are a direct, nonclassical target for thyroid-stimulating hormone. J Invest Dermatol 2009; 129: 1126-39.

176. Paus R. Exploring the "thyroid-skin connection": concepts, questions, and clinical relevance. J Invest Dermatol 2010; 130: 7-10.

177. Slominski AT, Brozyna AA, Tuckey RC. Cutaneous glucocorticoidogenesis and cortisol signaling are defective in psoriasis. J Invest Dermatol 2017; 137: 1609-11.

178. Slominski A. On the role of the corticotropin-releasing hormone signalling system in the aetiology of inflammatory skin disorders. Br J Dermatol 2009; 160: 229-32.

179. Karalis K, Sano H, Redwine J, et al. Autocrine or paracrine inflammatory actions of corticotropin-releasing hormone in vivo. Science 1991; 254: 421-3.

180. Crofford LJ, Sano H, Karalis K, et al. Local secretion of corticotropin-releasing hormone in the joints of Lewis rats with inflammatory arthritis. J Clin Invest 1992; 90: 2555-64.

181. Crofford LJ, Sano H, Karalis K, et al. Corticotropin-releasing hormone in synovial fluids and tissues of patients with rheumatoid arthritis and osteoarthritis. J Immunol 1993; 151: 1587-96.

182. Karalis K, Muglia LJ, Bae D, et al. CRH and the immune system. J Neuroimmunol 1997; 72: 131-6.

183. Benou C, Wang Y, Imitola J, et al. Corticotropin-releasing hormone contributes to the peripheral inflammatory response in experimental autoimmune encephalomyelitis. I Immunol 2005; 174: 5407-13.

184. Kempuraj D, Papadopoulou NG, Lytinas M, et al. Corticotropin-releasing hormone and its structurally related urocortin are synthesized and secreted by human mast cells. Endocrinology 2004; 145: 43-8.

185. Zbytek B, Pfeffer LM, Slominski AT. Corticotropin-releasing hormone stimulates NF-kappaB in human epidermal keratinocytes. J Endocrinol 2004; 181: R1-7.

186. Zbytek B, Slominski AT. CRH mediates inflammation induced by lipopolysaccharide in human adult epidermal keratinocytes. J Invest Dermatol 2007; 127: 730-2.

187. Slominski A, Zbytek B, Zmijewski M, et al. Corticotropin releasing hormone and the skin. Front Biosci 2006; 11: 2230-48.

188. Theoharides TC, Singh LK, Boucher W, et al. Corticotropinreleasing hormone induces skin mast cell degranulation and increased vascular permeability, a possible explanation for its proinflammatory effects. Endocrinology 1998; 139: 403-13.

189. Singh LK, Boucher W, Pang X, et al. Potent mast cell degranulation and vascular permeability triggered by urocortin through activation of corticotropin-releasing hormone receptors. J Pharmacol Exp Ther 1999; 288: 1349-56.

190. Singh LK, Pang X, Alexacos N, et al. Acute immobilization stress triggers skin mast cell degranulation via corticotropin releasing hormone, neurotensin, and substance $P$ : a link to neurogenic skin disorders. Brain Behav Immun 1999; 13: 225-39.

191. Kim JE, Cho DH, Kim HS, et al. Expression of the corticotropin-releasing hormone-proopiomelanocortin axis in the various clinical types of psoriasis. Exp Dermatol 2007; 16: 104-9.

192. Vasiadi M, Therianou A, Sideri K, et al. Increased serum $\mathrm{CRH}$ levels with decreased skin CRHR-1 gene expression in psoriasis and atopic dermatitis. J Allergy Clin Immunol 2012; 129: 1410-3.

193. Tagen M, Stiles L, Kalogeromitros D, et al. Skin corticotropin-releasing hormone receptor expression in psoriasis. J Invest Dermatol 2007; 127: 1789-91. 
194. Zhou C, Yu X, Cai D, et al. Role of corticotropin-releasing hormone and receptor in the pathogenesis of psoriasis. Med Hypotheses 2009; 73: 513-5.

195. Loite U, Kingo K, Reimann E, et al. Gene expression analysis of the corticotrophin-releasing hormone-proopiomelanocortin system in psoriasis skin biopsies. Acta Derm Venereol 2013; 93: 400-5.

196. Cemil BC, Canpolat F, Yilmazer D, et al. The association of PASI scores with CRH-R1 expression in patients with psoriasis. Arch Dermatol Res 2012; 304: 127-32.

197. Zhou CL, Yu XJ, Cai DX, et al. Inhibiting interleukin-18 production through the mitogen-activated protein kinase pathway, a potential role of corticotropin-releasing hormone in chronic plaque psoriasis. Inflammation 2015; 38: 1003-11.

198. Slominski A, Wortsman J, Mazurkiewicz JE, et al. Detection of proopiomelanocortin-derived antigens in normal and pathologic human skin. J Lab Clin Med 1993; 122: 658-66.

199. Kim JE, Cho BK, Cho DH, Park HJ. Expression of hypothalamic-pituitary-adrenal axis in common skin diseases: evidence of its association with stress-related disease activity. Acta Derm Venereol 2013; 93: 387-93.

200. Harvima IT, Nilsson G. Stress, the neuroendocrine system and mast cells: current understanding of their role in psoriasis. Expert Rev Clin Immunol 2012; 8: 235-41.

201. O'Kane M, Murphy EP, Kirby B. The role of corticotropinreleasing hormone in immune-mediated cutaneous inflammatory disease. Exp Dermatol 2006; 15: 143-53.

202. Hannen R, Udeh-Momoh C, Upton J, et al. Dysfunctional skin-derived glucocorticoid synthesis is a pathogenic mechanism of psoriasis. I Invest Dermatol 2017; 137: 1630-7.

203. Sarkar MK, Kaplan N, Tsoi LC, et al. Endogenous glucocorticoid deficiency in psoriasis promotes inflammation and abnormal differentiation. J Invest Dermatol 2017; 137: 1474-83.

204. Chrousos GP. Stress and disorders of the stress system. Nat Rev Endocrinol 2009; 5: 374-81.

205. Cawley NX, Li Z, Loh YP. 60 years of POMC: biosynthesis, trafficking, and secretion of pro-opiomelanocortin-derived peptides. J Mol Endocrinol 2016; 56: T77-97.

206. Kokkotou E, Torres D, Moss AC, et al. Corticotropin-releasing hormone receptor 2-deficient mice have reduced intestinal inflammatory responses. I Immunol 2006; 177: 3355-61.

207. Slominski A, Wortsman J, Pisarchik A, et al. Cutaneous expression of corticotropin-releasing hormone (CRH), urocortin, and CRH receptors. FASEB J 2001; 15: 1678-93.

208. Alysandratos KD, Asadi S, Angelidou A, et al. Neurotensin and $\mathrm{CRH}$ interactions augment human mast cell activation. PLoS One 2012; 7: e48934.

209. Theoharides TC. Neuroendocrinology of mast cells: challenges and controversies. Exp Dermatol 2017; 26: 751-9.

210. Ito N, Sugawara K, Bodó E, et al. Corticotropin-releasing hormone stimulates the in situ generation of mast cells from precursors in the human hair follicle mesenchyme. J Invest Dermatol 2010; 130: 995-1004.

211. Turnbull AV, Rivier CL. Regulation of the hypothalamic-pituitary-adrenal axis by cytokines: actions and mechanisms of action. Physiol Rev 1999; 79: 1-71.

212. Rousseau K, Kauser S, Pritchard LE, et al. Proopiomelanocortin (POMC), the ACTH/melanocortin precursor, is secreted by human epidermal keratinocytes and melanocytes and stimulates melanogenesis. FASEB J 2007; 21: 1844-56.

213. Zbytek B, Pfeffer LM, Slominski AT. CRH inhibits NF-kappa B signaling in human melanocytes. Peptides 2006; 27: 3276-83.
214. Yin $\mathrm{H}$, Zhang F, Yu M, et al. Beta-endorphin ameliorates synovial cell hyperfunction in the collagen-induced arthritis rat model by specific downregulation of NF-kappa B activity. Neuroendocrinology 2005; 81: 10-8.

215. Refojo D, Kovalovsky D, Young Jl, et al. Increased splenocyte proliferative response and cytokine production in beta-endorphin-deficient mice. J Neuroimmunol 2002; 131: 126-34.

216. Besedovsky HO, del Rey A. Immune-neuro-endocrine interactions: facts and hypotheses. Endocr Rev 1996; 17: 64-102.

217. Blalock JE. The syntax of immune-neuroendocrine communication. Immunol Today 1994; 15: 504-11.

218. Zmijewski MA, Slominski AT. Emerging role of alternative splicing of CRF1 receptor in CRF signaling. Acta Biochim Pol 2010; 57: 1-13.

219. Zmijewski MA, Slominski AT. CRF1 receptor splicing in epidermal keratinocytes: potential biological role and environmental regulations. J Cell Physiol 2009; 218: 593-602.

220. Zmijewski MA, Slominski AT. Modulation of corticotropin releasing factor (CRF) signaling through receptor splicing in mouse pituitary cell line AtT-20 - emerging role of soluble isoforms. J Physiol Pharmacol 2009; 60, Suppl 4: 39-46.

221. Pisarchik A, Slominski AT. Alternative splicing of CRH-R1 receptors in human and mouse skin: identification of new variants and their differential expression. FASEB J 2001; 15: 2754-6.

222. Archid R, Duerr HP, Patzelt A, et al. Relationship between histological and clinical course of psoriasis: a pilot investigation by reflectance confocal microscopy during Goeckerman treatment. Skin Pharmacol Physiol 2016; 29: 47-54.

223. Micali G, Lacarrubba F, Musumeci ML, et al. Cutaneous vascular patterns in psoriasis. Int I Dermatol 2010; 49: 249-56.

224. Hendriks AG, Steenbergen W, Zeeuwen PL, et al. Perfusion intensity correlates with expression levels of psoriasisrelated genes and proteins. Skin Pharmacol Physiol 2015; 28: 296-306.

225. Boehncke WH, Schön MP. Psoriasis. Lancet 2015; 386: 983-94.

226. Bressan AL, Picciani BLS, Azulay-Abulafia L, et al. Evaluation of ICAM-1 expression and vascular changes in the skin of patients with plaque, pustular, and erythrodermic psoriasis. Int J Dermatol 2018; 57: 209-16.

227. Archid R, Patzelt A, Lange-Asschenfeldt B, et al. Confocal laser-scanning microscopy of capillaries in normal and psoriatic skin. J Biomed Opt 2012; 17: 101511.

228. Braverman IM, Yen A. Ultrastructure of the human dermal microcirculation. II. The capillary loops of the dermal papillae. J Invest Dermatol 1977; 68: 44-52.

229. Braverman IM, Yen A. Ultrastructure of the capillary loops in the dermal papillae of psoriasis. J Invest Dermatol 1977; 68: 53-60.

230. Braverman IM, Sibley J. Role of the microcirculation in the treatment and pathogenesis of psoriasis. J Invest Dermatol 1982; 78: 12-17.

231. Deubelbeiss C, Kolios AGA, Anzengruber F, et al. TNFalpha and IL-17A are differentially expressed in psoriasis-like vs eczema-like drug reactions to TNFalpha antagonists. J Cutan Pathol 2018; 45: 23-28.

232. Guérard S, Pouliot R. The role of angiogenesis in the pathogenesis of psoriasis: mechanisms and clinical implications. J Clin Exp Dermatol Res 2012; S: 2.

233. Hendriks AG, Steenbergen W, Hondebrink E, et al. Whole field laser Doppler imaging of the microcirculation in psoriasis and clinically unaffected skin. J Dermatolog Treat 2014; 25: 18-21. 
234. Malecic N, Young HS. Excessive angiogenesis associated with psoriasis as a cause for cardiovascular ischaemia. Exp Dermatol 2017; 26: 299-304.

235. Teixeira GG, Mari NL, de Paula JCC, et al. Cell adhesion molecules, plasminogen activator inhibitor type 1 , and metabolic syndrome in patients with psoriasis. Clin Exp Med 2020; 20: 39-48.

236. Deng W, Feng X, Li X, et al. Hypoxia-inducible factor 1 in autoimmune diseases. Cell Immunol 2016; 303: 7-15.

237. Torales-Cardeńa A, Martínez-Torres I, Rodríguez-Martínez S, et al. Cross talk between proliferative, angiogenic, and cellular mechanisms orchestred by HIF-1alpha in psoriasis. Mediators Inflamm 2015; 2015: 607363.

238. Cantatore FP, Maruotti N, Corrado A, et al. Angiogenesis dysregulation in psoriatic arthritis: molecular mechanisms. Biomed Res Int 2017; 2017: 5312813.

239. Varricchi G, Granata F, Loffredo S, et al. Angiogenesis and lymphangiogenesis in inflammatory skin disorders. J Am Acad Dermatol 2015; 73: 144-53.

240. Xian D, Song J, Yang L, et al. Emerging roles of redox-mediated angiogenesis and oxidative stress in dermatoses. Oxid Med Cell Longev 2019; 2019: 2304018.

241. Marina ME, Roman II, Constantin AM, et al. VEGF involvement in psoriasis. Clujul Med 2015; 88: 247-52.

242. Detmar M, Brown LF, Claffey KP, et al. Overexpression of vascular permeability factor/vascular endothelial growth factor and its receptors in psoriasis. J Exp Med 1994; 180: 1141-6.

243. Akman A, Yilmaz E, Mutlu H, et al. Complete remission of psoriasis following bevacizumab therapy for colon cancer. Clin Exp Dermatol 2009; 34: e202-4

244. Li W, Man XY, Chen JQ, et al. Targeting VEGF/VEGFR in the treatment of psoriasis. Discov Med 2014; 18: 97-104.

245. Batycka-Baran A, Paprocka M, Krawczenko A, et al. Reduced number of circulating endothelial progenitor cells (CD133+/KDR+) in patients with plaque psoriasis. Dermatology 2012; 225: 88-92

246. Hu SC, Lan CE. Psoriasis and cardiovascular comorbidities: focusing on severe vascular events, cardiovascular risk factors and implications for treatment. Int J Mol Sci 2017; 18: E2211.

247. Amin M, Lee EB, Tsai TF, et al. Psoriasis and co-morbidity. Acta Derm Venereol 2020; 100: adv00033

248. Armstrong EJ, Harskamp CT, Armstrong AW. Psoriasis and major adverse cardiovascular events: a systematic review and meta-analysis of observational studies. J Am Heart Assoc 2013; 2: e000062.

249. Gelfand JM, Dommasch ED, Shin DB, et al. The risk of stroke in patients with psoriasis. J Invest Dermatol 2009; 129: 2411-8.

250. Shiba M, Kato T, Funasako M, et al. Association between psoriasis vulgaris and coronary heart disease in a hospitalbased population in Japan. PLoS One 2016; 11: e0149316.

251. Yim KM, Armstrong AW. Updates on cardiovascular comorbidities associated with psoriatic diseases: epidemiology and mechanisms. Rheumatol Int 2017; 37: 97-105.

252. Lai YC, Yew YW. Psoriasis as an independent risk factor for cardiovascular disease: an epidemiologic analysis using a national database. J Cutan Med Surg 2016; 20: 327-33.

253. Wu JJ, Choi YM, Bebchuk JD. Risk of myocardial infarction in psoriasis patients: a retrospective cohort study. J Dermatolog Treat 2015; 26: 230-4.

254. Elsheikh RG, Amin Tel-S, El-Ashmawy AA, et al. Evaluation of subclinical atherosclerosis in Egyptian psoriatic patients. J Saudi Heart Assoc 2014; 26: 63-71.
255. Enany B, El Zohiery AK, Elhilaly R, et al. Carotid intimamedia thickness and serum leptin in psoriasis. Herz 2012; 37: 527-33.

256. Ergun T, Yazici V, Yavuz D, et al. Advanced glycation end products, a potential link between psoriasis and cardiovascular disease: a case-control study. Indian J Dermatol 2019; 64: 201-6.

257. Gonzalez-Cantero A, Gonzalez-Cantero J, Sanchez-Moya Al, et al. Subclinical atherosclerosis in psoriasis. Usefulness of femoral artery ultrasound for the diagnosis, and analysis of its relationship with insulin resistance. PLoS One 2019; 14: e0211808.

258. Haberka M, Bańska-Kisiel K, Bergler-Czop B, et al. Mild to moderate psoriasis is associated with oxidative stress, subclinical atherosclerosis, and endothelial dysfunction. Pol Arch Intern Med 2018; 128: 434-9.

259. Fang N, Jiang M, Fan Y. Association between psoriasis and subclinical atherosclerosis: a meta-analysis. Medicine (Baltimore) 2016; 95: e3576.

260. Batycka-Baran A, Paprocka M, Krawczenko A, et al. Increased number of circulating endothelial cells (CECS) in patients with psoriasis - preliminary report. J Eur Acad Dermatol Venereol 2014; 28: 116-9.

261. Batycka-Baran A, Baran W, Nowicka-Suszko D, et al. Soluble receptor for advanced glycation end products: a novel biomarker for psoriasis severity with therapeutic implications? Acta Derm Venereol 2018; 98: 797-8.

262. Papagrigoraki A, Maurelli M, Del Giglio M, et al. Advanced glycation end products in the pathogenesis of psoriasis. Int J Mol Sci 2017; 18: E2471.

263. Xie J, Mendez DJ, Mendez-Valenzuela V, et al. Cellular signalling of the receptor for advanced glycation end products (RAGE). Cell Sign 2013; 25: 2185-97.

264. Braley A, Kwak T, Jules J, et al. Regulation of receptor for advanced glycation end products (RAGE) ectodomain shedding and its role in cell function. J Biol Chem 2016; 291: 12057-73

265. Ramasamy R, Shekhtman A, Schmidt AM. The multiple faces of RAGE-opportunities for therapeutic intervention in aging and chronic disease. Expert Opin Ther Targets 2016; 20: 431-46.

266. Batycka-Baran A, Hattinger E, Zwicker S, et al. Leukocytederived koebnerisin (S100A15) and psoriasin (S100A7) are systemic mediators of inflammation in psoriasis. J Dermatol Sci 2015; 79: 214-21.

267. Papagrigoraki A, Del Giglio M, Cosma C, et al. Advanced glycation end products are increased in the skin and blood of patients with severe psoriasis. Acta Derm Venereol 2017; 97: 782-7.

268. Kaur S, Zilmer K, Leping V, et al. Serum methylglyoxal level and its association with oxidative stress and disease severity in patients with psoriasis. Arch Dermatol Res 2013; 305: 489-94.

269. Kopeć-Pyciarz K, Makulska I, Zwolińska D, et al. Skin autofluorescence, as a measure of AGE accumulation in individuals suffering from chronic plaque psoriasis. Mediators Inflamm 2018; 2018: 4016939.

270. Vazzana N, Santilli F, Cuccurullo C, et al. Soluble forms of RAGE in internal medicine. Intern Emerg Med 2009; 4: 389-401. 